\title{
Soil organic matter accounting in the carbon footprint analysis of the wine chain
}

\author{
Simona Bosco • Claudia Di Bene • Mariassunta Galli • \\ Damiano Remorini • Rossano Massai • Enrico Bonari
}

Received: 14 February 2012 / Accepted: 8 March 2013 / Published online: 9 April 2013

(C) Springer-Verlag Berlin Heidelberg 2013

\begin{abstract}
Purpose Concerns about global warming led to the calculation of the carbon footprint (CF) left by human activities. The agricultural sector is a significant source of greenhouse gas (GHG) emissions, though cropland soils can also act as sinks. So far, most LCA studies on agricultural products have not considered changes in soil organic matter (SOM). This paper aimed to: (1) integrate the Hénin-Dupuis SOM model into the CF study and (2) outline the impacts of different vineyard soil management scenarios on the overall $\mathrm{CF}$.

Methods A representative wine chain in the Maremma Rural District, Tuscany (Italy), made up of a cooperative winery and nine of its associated farms, was selected to investigate the production of a non-aged, high-quality red wine. The system boundary was established from vineyard planting to waste management after use. The functional unit (FU) chosen for this study was a 0.75 -L bottle of wine, and all data refer to the year 2009. The SOM balance, based on Hénin-Dupuis' equation, was integrated and run using GaBi4 software. A sensitivity analysis was performed, and four scenarios were developed to assess the impact of vineyard soil management types with decreasing levels of organic matter inputs.

Results and discussion SOM accounting reduced the overall $\mathrm{CF}$ of one wine bottle from 0.663 to $0.531 \mathrm{~kg} \mathrm{CO}_{2}$-eq/FU.
\end{abstract}

Responsible editor: Gérard Gaillard

Simona Bosco and Claudia Di Bene contributed equally to this work.

S. Bosco $(\bowtie) \cdot$ C. Di Bene $\cdot$ M. Galli $\cdot$ E. Bonari

Institute of Life Sciences, Scuola Superiore Sant'Anna,

P.zza Martiri della Libertà 33, 56127 Pisa, Italy

e-mail: s.bosco@sssup.it

D. Remorini $\cdot$ R. Massai

Department of Agriculture, Food and Environment (DAFE),

University of Pisa, Via del Borghetto 80,

56124 Pisa, Italy
The vineyard planting sub-phase produced a loss of SOM while, in the pre-production and production sub-phases, the loss/accumulation of SOM was related to the soil management practices. On average, soil management in the production sub-phase led to a net accumulation of SOM, and the overall vineyard phase was a sink of $\mathrm{CO}_{2}$. Residue incorporation and grassing were identified as the main factors affecting changes in SOM in vineyard soils.

Conclusions Our results showed that incorporating SOM accounting into the wine chain's $\mathrm{CF}$ analysis changed the vineyard phase from a GHG source to a modest net GHG sink. These results highlighted the need to include soil C dynamics in the $\mathrm{CF}$ of the agricultural product. Here, the SOM balance method proposed was sensitive to changes in management practices and was site specific. Moreover, we were also able to define a minimum data set for SOM accounting.

The EU recognises soil carbon sequestration as one of the major European strategies for mitigation. However, specific measures have yet to be included in the CAP 2020. It would be desirable to include soil in the new ISO 14067-Carbon Footprint of Products.

Keywords Agriculture mitigation potential · Food LCA . Greenhouse gas emissions · Soil organic matter model · Vineyard soil management $\cdot$ Wine

\section{Introduction}

Concerns about greenhouse gas (GHG) emissions and their effect on global warming have led to the calculation of the carbon footprint (CF) of many areas of human activity. The $\mathrm{CF}$ is a measurement of the amount of GHGs released during a product's life cycle. There is much debate around the precise definition of the $\mathrm{CF}$, and more still regarding what methodology to use to calculate it (Finkbeiner 2009; 
Wiedmann 2009; Wright et al. 2011). Recently, the European Society of Environmental Toxicology and Chemistry (SETAC Europe) LCA Steering Committee and the academic world as a whole formally recognised the importance of developing a simplified method for evaluating the CF of a product. Moreover, this attitude has become increasingly prominent and widespread over recent years, with the calculation of the environmental impact of a production chain assuming importance as a means of informing environmentally conscious consumers in their quest for the most climate-friendly food (Milà i Canals 2006; Avraamides 2008; Weidema et al. 2008; Meisterling et al. 2009; Roy et al. 2009). Calculating the $\mathrm{CF}$ of food products presents specific difficulties for life cycle inventory (LCI) data collection, since the processes involved cannot be easily standardised (Cowell and Clift 1997; Haaset al. 2000; Mourad et al. 2007). As Nemecek and Erzinger (2005) indicated, farms have high variability in both natural factors (climate, soil etc.) and management factors (farm size, cropping management etc.), and by difficult-to-measure emissions.

Today, agricultural activities constitute a significant source of $\mathrm{CO}_{2}, \mathrm{CH}_{4}$, and $\mathrm{N}_{2} \mathrm{O}$ emissions. However, the implementation of sustainable management practices within agricultural systems has been shown to reduce these emissions, attributable to the natural capacity of agricultural soils to absorb and store $\mathrm{CO}_{2}$ (Janssens et al. 2003). This means that the role of agriculture centres on a conservative soil management designed both to protect soil quality and encourage GHG emission reduction (Smith et al. 2008). It is well-established that unsuitable agricultural practices, such as deep tillage, over-fertilisation, excessive use of pesticides and irrigation and the removal of crop residues can dramatically affect soil quality (Lal 2004, 2008). Consequently, soil management practices and their impact on soil quality are fundamental factors to consider when evaluating the sustainability of agricultural systems. In terms of soil quality, soil organic matter (SOM) balance can profoundly affect estimates of the overall sustainability of agricultural systems, as has been reported by many studies (Loveland and Webb 2003; Manlay et al. 2007; Feller and Bernoux 2008).

Attention has already been drawn to the crucial importance of the role of soil quality and SOM in the life cycle of agricultural products (Cowel and Clift 1997; Cowell et al. 2000). Nevertheless, many LCA studies of food and nonfood products do not take into account changes in SOM in arable cropland (Brentup et al. 2004; Milà i Canals et al. 2006; Mourad et al. 2007; Hillier et al. 2009; Roy et al. 2009). This remains something of an unresolved issue in LCA, as a result of spatial and temporal variability and the influence of microclimate on soil quality (Reap et al. 2008). Bala et al. (2010) attempted to standardise CF methodology without taking soil into consideration within the system boundary. Also, in the 2006 and 2011 versions of PAS 2050 - the most widely recognised guideline for assessing life cycle GHG emissions by goods and services-soil emissions were not considered except in instances of landuse changes (BSI 2008; 2011; Sinden 2009).

To date, few studies have incorporated soil into an LCA (Milà i Canals et al. 2006; Meisterling et al. 2009; Nemecek et al. 2011; Ponsioen and Blonk 2011) and no common methodology for its estimation and LCA inclusion currently exists. Milà i Canals et al. (2007) developed an approach which proposes SOM as the sole indicator of soil quality. Koerber et al. (2009) evaluated the carbon balance of the agroecosystem by measuring $\mathrm{CO}_{2}$ fluxes and stressed the importance of soil emissions in the overall life cycle of vegetables. Brandão et al. (2011) used soil organic carbon changes as the key indicator for assessing the performance of various bioenergy feedstocks.

As mentioned, soil quality and SOM changes are strongly influenced by management practices and soil and climate conditions, and are therefore entirely site specific. This is why many authors have highlighted the need for detailed site-specific modelling of SOM changes in LCA studies of agricultural products (Müller-Wenk and Brandão 2010; Brandão et al. 2011). Consequently, the use of default values for soil GHG emissions and/or absorption should be avoided, as should the uncertainty associated with entering inaccurate input values into models.

Many process-oriented SOM models are available for predicting its dynamics on a daily, monthly or annual basis, with the most frequently adopted being Century (Parton et. al 1987), RothC (Jenkinson and Rayner 1977; Jenkinson 1990) and DNDC (Li et al. 1992a, b). Some of these models have already been incorporated into LCA analysis (Milà i Canals et al. 2007; Hillier et al. 2009; Soja et al. 2010). However, the huge amount of data required (meteorological data, crop phenological data and chemical and physical soil characteristics) to run these models and establish the LCI could limit widespread use of this approach. A simpler onecompartment SOM model would be more easily integrated into the LCA study. Recently, many authors have adopted the Hénin-Dupuis SOM model (1945) for cropping system and orchard studies under different climate conditions, and it has been useful for less-detailed modelling at sites where input requirements for running the more complex models are not readily available (Andriulo et al. 1999; Sofo et al. 2005; Bockstaller et al. 2008; Bertora et al. 2009; Bechini et al. 2011; Di Bene et al. 2011). This model has reflected SOM variations over a 10- to 100 -year period well (Andren et al. 2004; Kemanian et al. 2005; Bayer et al. 2006).

We integrated the Hénin-Dupuis SOM model into a CF analysis of wine to test the impact of different management practices on the overall result. Wine was chosen as a case study because it is already a widely studied food product 
(Aranda et al. 2005; Ardente et al. 2006; Pizzigallo et al. 2008; Gazulla et al. 2010; Soja et al. 2010; Colman and Päster 2009) and because of its importance within international and Italian food markets. Moreover, many international organisations for wine production, such as the International Wine Carbon Calculator (IWCC) and the Organisation Internationale de la Vigne et $d u$ Vin (OIV), are working to have soil included within the wine CF estimation protocols and guidelines currently under development (Pittock et al. 2003; Hayes and Battaglene 2006; Webb et al. 2007; Forsyth and Oemcke 2008).

Our study formed part of the "Carbon Label Project", founded by the Italian Institute for Foreign Trade in collaboration with the Province of Grosseto(Tuscany, Italy) local government. The project was launched in the Maremma Rural District in 2008 to evaluate the environmental performances of wine, olive oil and fruit production, the region's primary food chains (Bosco et al. 2011).

The purposes of this paper are (1) to propose an answer to the current debate on how to incorporate soil into the CF analysis of agri-food chains, by integrating the HéninDupuis SOM model into the CF analysis of wine, and (2) to highlight the potential of viticulture as a means of mitigating GHG emissions, investigating the impact of different vineyard soil management techniques on the overall $\mathrm{CF}$.

\section{Methodology}

\subsection{Goal}

The aim of this study is to carry out CF analysis of wine, with the inclusion of a SOM model. The specific objectives are as follows:

- Integration of a simplified model for SOM pool assessment into a wine $\mathrm{CF}$

- Evaluation of how different soil management practices can affect the overall $\mathrm{CF}$

Our investigations focused on a representative wine chain in the Maremma Rural District, Tuscany (Italy) and the production of non-aged, high-quality red wine. Specifically, the chain is made up of a cooperative winery and some of its associated farms.

\subsection{Functional unit, systems boundary and allocations}

The functional unit (FU) used for the study was one $0.75 \mathrm{~L}$ bottle of wine, and all data refer to the year 2009. The production of $0.75 \mathrm{~L}$ of wine in the winery required $1.24 \mathrm{~kg}$ of grapes and approximately $1.37 \mathrm{~m}^{2}$ of productive vineyard, based on a fixed yield of $9 \mathrm{Mg} \mathrm{ha}^{-1}$ year $^{-1}$, as imposed on all associated farms by the regulatory board of the corresponding controlled and guaranteed denomination of origin (DOCG). The analysis was performed using the GaBi4 software package developed by PE International (GaBi4 2007a), the bundled professional database (GaBi4 2007b) and the ecoinvent database (EcoInvent Centre 2007). The method used here for the global warming potential (GWP) impact category was CML, version 2009 (Guinée et al. 2002).

The system boundary was divided into two main phases, the vineyard and the winery, comprising eight sub-phases (Fig. 1). Most existing LCA studies of wine do not consider the vineyard planting sub-phase (Notarnicola et al. 2003; Ardente et al. 2006; Gazulla et al. 2010; Petti et al. 2010). We included it in this study because of its agronomic importance and potential impact on GHG emissions.

Allocation on a mass basis was used to distribute impact between the various co-products of the vinification process (skins, pips and stalks). The stalks were reused in farms as organic fertiliser, while the pips and skins were sent to the distillery for spirit production. Transportation to the distillery and the distillation process itself were not included. All transportation for material supply and waste disposal were included.

For this study, GWP impact was estimated by considering the $\mathrm{CO}_{2}, \mathrm{CH}_{4}$ and $\mathrm{N}_{2} \mathrm{O}$ emissions associated with energy and material inputs during each sub-phase of the production chain. Biogenic $\mathrm{CO}_{2}$ emissions were not considered, according to the IPCC Guidelines (IPCC 2006). In the guidelines, biogenic $\mathrm{C}$ in annual crop biomass is not considered, neither as $\mathrm{C}$ sequestered during crop growth nor as $\mathrm{C}$ lost at harvesting, because they are considered as part of the short-term carbon cycle. In the case of the wine chain, these emission sources included non-permanent vineyard growth, grape growth, $\mathrm{CO}_{2}$ emissions from the combustion of biomass fuels and grape fermentation. Indeed, grape fermentation releases the same $\mathrm{CO}_{2}$ fixed by photosynthesis in grape biomass in the previous months.

Carbon is stored in various pools within the vineyard system, for example in permanent and short-lived vine structures and various SOM pools (Carlisle et al. 2010). $\mathrm{CO}_{2}$ emissions/removal caused by $\mathrm{C}$-stock changes in vine biomass were not included, since its $\mathrm{C}$ pool is considerably smaller $(<1 \%$ the size) than that of the soil (Keightley 2011), and the corresponding vine biomass $\mathrm{C}$ pool is removed at the end of the vineyard production period. Direct and indirect $\mathrm{N}_{2} \mathrm{O}$ soil emissions from synthetic and organic fertilisers were calculated using IPCC methodology and emissions factors (IPCC 2006).

\subsection{Soil organic matter model}

We implemented Cowell and Clift (2000), which considers only OM inputs, in accordance with many studies on soil dynamics (Bockstaller and Girandin 2003; Bechini and 


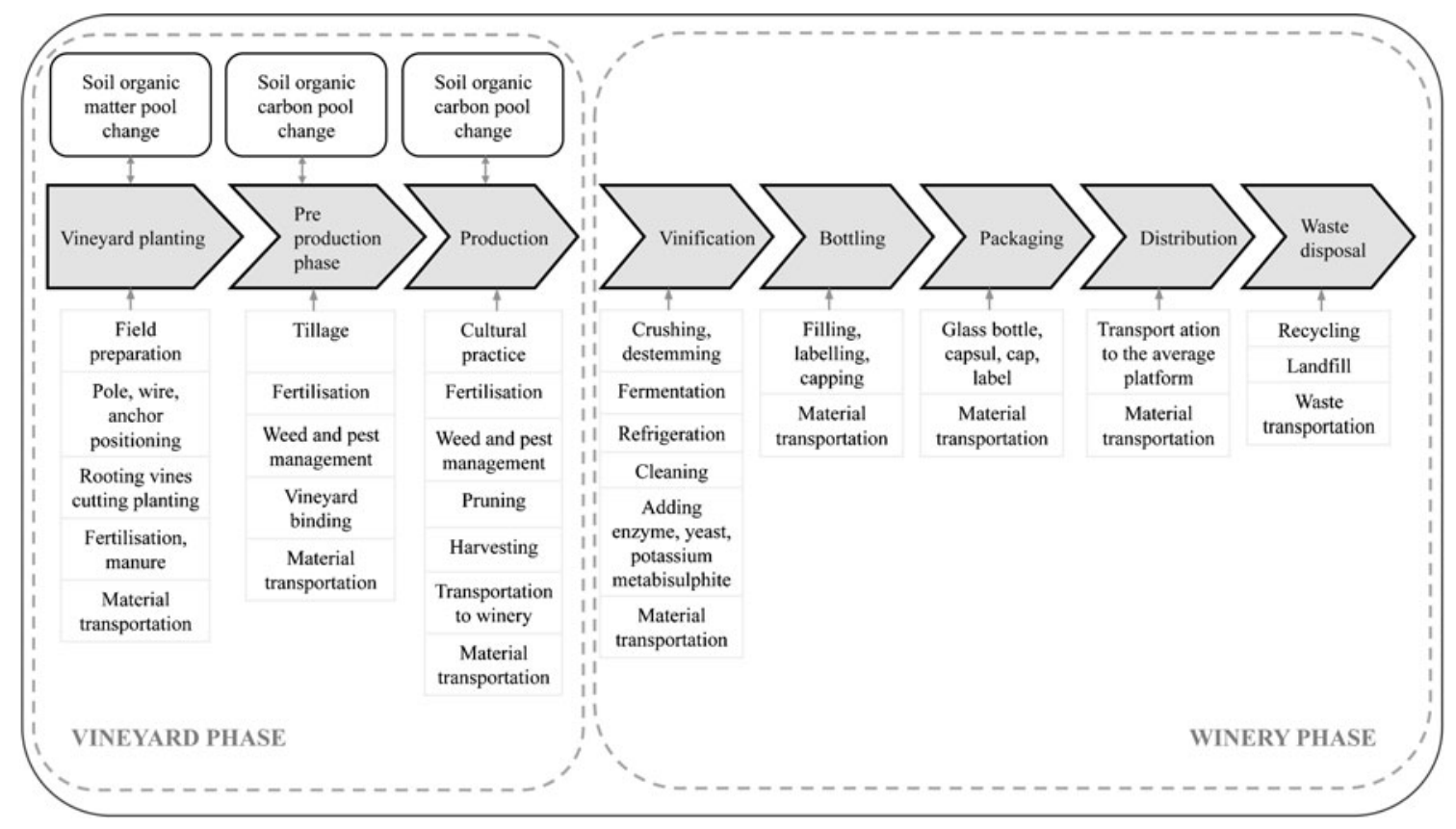

Fig. 1 System boundaries diagram of the red-wine production chain

Castoldi 2009). Here, we used the SOM model (Fig. 2), based on the first-order kinetics model developed by Hénin and Dupuis (1945), to evaluate the effect of agricultural practices on the change in the SOM pool and can be described by the following equation:

$\mathrm{SOM}_{t}=\mathrm{SOM}_{0} \mathrm{e}^{-k}{ }_{2} t+k_{1} \mathrm{OM}_{\mathrm{I}} / k_{2}\left(1-\mathrm{e}^{-k_{2} t}\right)$

where $\mathrm{SOM}_{t}$ is the $\mathrm{SOM}$ pool $\left(\mathrm{Mg} \mathrm{ha}^{-1}\right)$ at time $t ; \mathrm{SOM}_{0}$ is the initial SOM pool $\left(\mathrm{Mg} \mathrm{ha}^{-1}\right)$ at time $t=0 ; k_{2}$ is the mineralisation coefficient corresponding to the annual rate of SOM loss by mineralisation; $k_{1}$ is the humification coefficient and refers to the annual rate of organic matter (OM) inputs incorporated in $\mathrm{SOM}$; and $\mathrm{OM}_{\mathrm{I}}$ is the annual $\mathrm{OM}$ inputs $\left(\mathrm{Mg} \mathrm{ha}^{-1}\right)$.

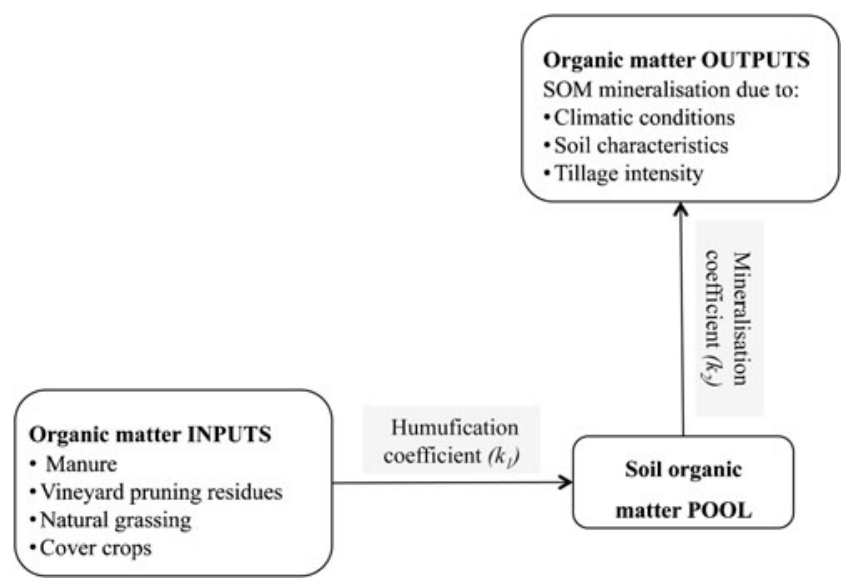

Fig. 2 Hénin-Dupuis soil organic matter model
The first component of Eq. $1, \mathrm{SOM}_{0} \mathrm{e}^{-k}{ }_{2}^{t}$, represents the fraction of $\mathrm{SOM}_{0}$ still in the soil at time $t$. The second component, $k_{1} \mathrm{OM}_{\mathrm{I}} / k_{2}\left(1-\mathrm{e}^{-k}{ }_{2}\right)$, is the fraction of the $\mathrm{SOM}$ pool deriving from the humification of organic material inputs since $t=0$.

The SOM pool was calculated according to the following equation:

SOM pool $=\left(\mathrm{SOM}_{c} \mathrm{BD} d A\right) / 100$

where SOM pool is OM stock $\left(\mathrm{Mg} \mathrm{ha}^{-1}\right) ; \mathrm{SOM}_{c}$ is $\mathrm{SOM}$ concentration $\left(\mathrm{g} \mathrm{kg}^{-1}\right)$, as determined using the modified Walkley-Black wet combustion method (Nelson and Sommers 1982); BD is soil bulk density $\left(\mathrm{g} \mathrm{cm}^{-3}\right)$, measured by the Culley method (1993); $d$ is soil sampling depth $(0.30 \mathrm{~m})$ and $A$ is the area being considered $\left(1 \mathrm{ha}=10,000 \mathrm{~m}^{2}\right)$.

For the quantification of the OM inputs $\left(\mathrm{OM}_{\mathrm{I}}\right)$ we identified different fractions of $\mathrm{OM}$ originating from grapevine (leaves and pruning residues), natural grass cover (aboveground and below-ground biomass), cover crops (aboveand below-ground biomass) and manure. For each of these inputs we considered a specific $k_{1}$ according to Boffin et al. (1986) and Fregoni (1989) (Table 1).

The mineralisation coefficient $\left(k_{2}\right)$ is affected by air temperature, soil texture and soil limestone content. As in Boiffin et al. (1986) and Bockstaller and Girardin (2003), $k_{2}$ was calculated as follows:

$k_{2}=1,200 f_{\theta}[(c+200)(l+200)]$

where $f_{\theta}$ is a temperature factor given by $f_{\theta}=0.2(T-5), T$ is mean annual air temperature $\left({ }^{\circ} \mathrm{C}\right), c$ is clay content $\left(\mathrm{g} \mathrm{kg}^{-1}\right)$ 
Table 1 Humification coefficient $\left(k_{1}\right)$ values of the organic matter input $\left(\mathrm{OM}_{\mathrm{I}}\right)$ considered (Fregoni 1989; Boiffin et al. 1986)

\begin{tabular}{ll}
\hline Input & $k_{1}$ value \\
\hline Grapevine & \\
Leaves & 0.10 \\
Stalks & 0.20 \\
Pruning residues & 0.30 \\
Inter-row grassing & \\
$\begin{array}{l}\text { Above-ground } \\
\text { biomass }\end{array}$ & 0.20 \\
Below-ground & \\
$\quad$ biomass & 0.20 \\
Manure & 0.30 \\
\hline
\end{tabular}

and $l$ is limestone content $\left(\mathrm{g} \mathrm{kg}^{-1}\right)$. A dimensionless correction factor of the mineralisation coefficient $(P)$, as proposed by Mary and Guerif (1994) and Bechini et al. (2011), was used to include farm soil management. $P$ was calculated as:

$P=p_{r} f_{r} I T_{S}$

where $p_{r}$ equals $0.0333 \times$ maximum crop plough depth $(D)$; $f_{r}$ is a coefficient considering crop management (for example, frequency of ploughing, frequency of residue incorporation, manure) as proposed by Mary and Guerif (1994); I is the mineralisation weight factor (1.25 and 1.00 for irrigated and non-irrigated crops, respectively) and $T_{s}$ is the tillage factor ( 1 where the soil is ploughed at least once every 4 years, 0.5 for non-tillage management and 0.8 for intermediate cases).

The Hénin-Dupuis model was integrated into and run using the GaBi4 software by creating a parameterised process for each vineyard sub-phase. Thus, SOM changes were predicted for each farm for the lifetime estimated for each vineyard (Table 2). The results for each sub-phase were allocated on the basis of their duration (in years) and normalised for 1 year. The results obtained, expressed in $\mathrm{Mg}$ SOM ha ${ }^{-1}$, were converted into $\mathrm{Mg} \mathrm{CO}_{2} \mathrm{ha}^{-1}$ using a $\mathrm{SOM} / \mathrm{SOC}$ ratio of 1.724 (van Bemmelen factor, in Nelson and Sommers 1982) and $\mathrm{CO}_{2} / \mathrm{C}$ molar mass ratio of 3.66 (44 $\mathrm{g} \mathrm{mole}^{-1} \mathrm{CO}_{2} / 12 \mathrm{~g} \mathrm{~mole}^{-1} \mathrm{C}$ ).

\subsection{Data collection}

The area of study was the hilly inland region in the Province of Grosseto, Southern Tuscany, Italy (latitude $42.9-42.6^{\circ} \mathrm{N}$; altitude $46-156 \mathrm{~m}$ a.s.1.). Climate is typically Mediterranean, characterised by two main rainy seasons in the autumn (from September to December) and the spring (from March to May), and annual rainfall of around $800 \mathrm{~mm}$. Mean temperature is $14.5^{\circ} \mathrm{C}$, and the warmest month of the year is July, with a mean temperature of $23^{\circ} \mathrm{C}$. Soils are quite variable and mostly shallow, with a texture ranging from silt loam to clay, with coarse fragments present in the upper layer $(0-50 \mathrm{~cm})$. According to the USDA classification, dominant soils include Lithic Xerorthents, Typic Ustorthents and Typic Dystrustepts (Soil Survey Staff 1975).

The collection of data about the wine production chain was organised through preliminary meetings between the winery director, an oenologist and an agronomist, to select the sample of farms from among the 100 or so associated farms spanning an area of around 400 ha. The farm sample was selected using vineyard management technique as the main criteria (see Table 2). The sample consisted of nine farms, accounting for $10 \%$ of all associated farms and $15 \%$ of the associated farm area. The main physical and chemical characteristics of the soil at the farms investigated are reported in Table 3.

Data selection was at the farm level, assuming homogeneous soil management all fields of the same farm. The main characteristics of the selected farms are reported in Table 3. The main differences in the vineyard soil management among the farms are related to manure distribution at vineyard planting, grass cover and residue management during the production sub-phase.

Primary data were collected through individual questionnaires for each sub-phase of the wine production chain, carried out in the form of personal interviews with the farmers and oenologist. The questionnaires included both quantitative inputs (diesel, electricity, natural gas, poles, wire, fertilisers, pesticides etc.) and outputs (product, coproducts, wastes etc.), and qualitative data (tillage at vineyard planting, presence of irrigation systems, residues and inter-row management etc.).

Energy and material inputs for the vineyard planting subphase were allocated in relation to the lifespan of each vineyard (20-30 years). The same approach was used for the preproduction sub-phase, which lasted 3 years at all farms. For the production sub-phase, all field operations were considered through to harvesting and transportation to the winery.

For the wine-making sub-phase, all energy consumed during grape crushing, fermentation, refrigeration, filtration and bottling were included. The packaging sub-phase included both primary and secondary packaging. The wine itself was bottled in green 0.75 - $\mathrm{L}$ glass bottles weighing $0.4 \mathrm{~kg}$ each, while secondary packaging consisted of a sixbottle cardboard box, sent out by truck in standard European pallets. For the distribution sub-phase, average transportation distance from the gates of the winery to the corresponding distribution platform equalled around $350 \mathrm{~km}$. Tables 4 and 5 list the main direct inputs across the whole of the production chain for the vineyard and winery phases, respectively.

Data on vineyard soil management, such as manure distribution, use of pruning residues and inter-row vineyard grass cover or grassing were collected using the aforementioned 
王

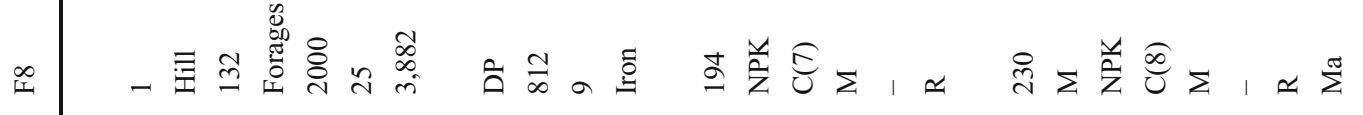

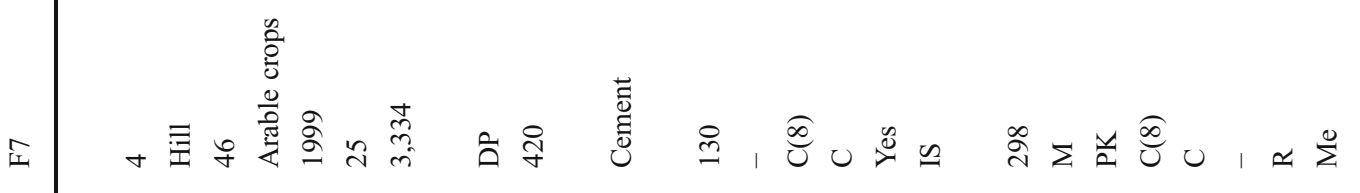

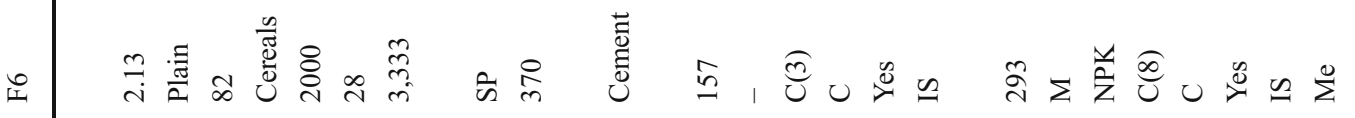

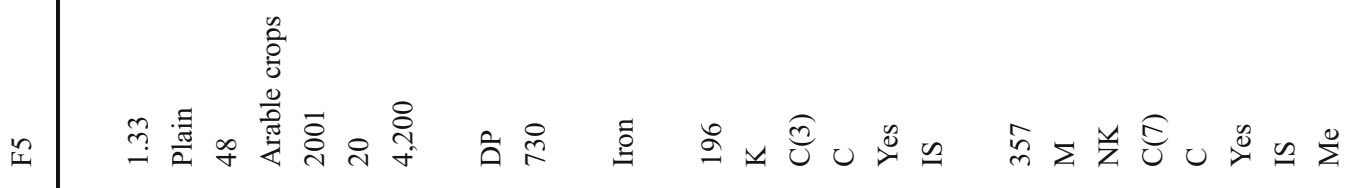

咅

(3)

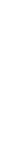

穿

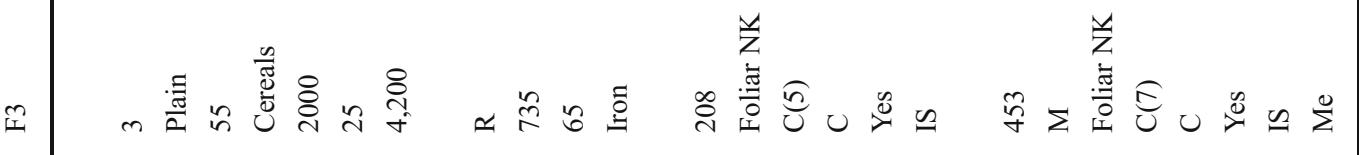

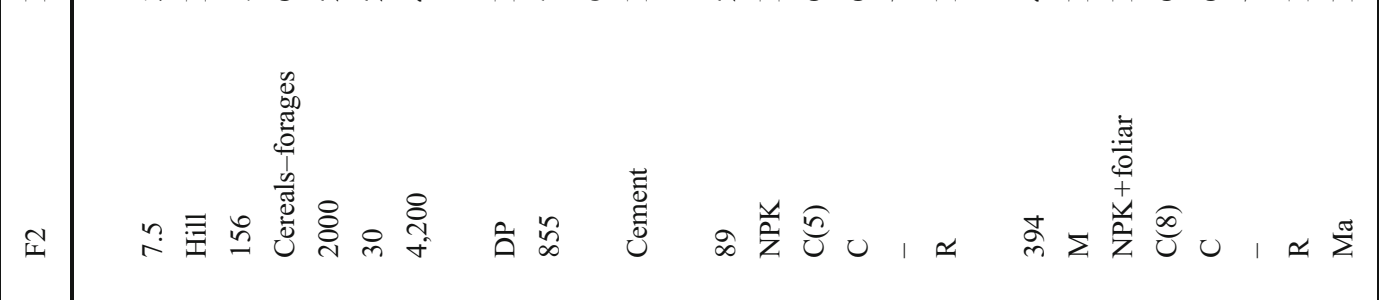

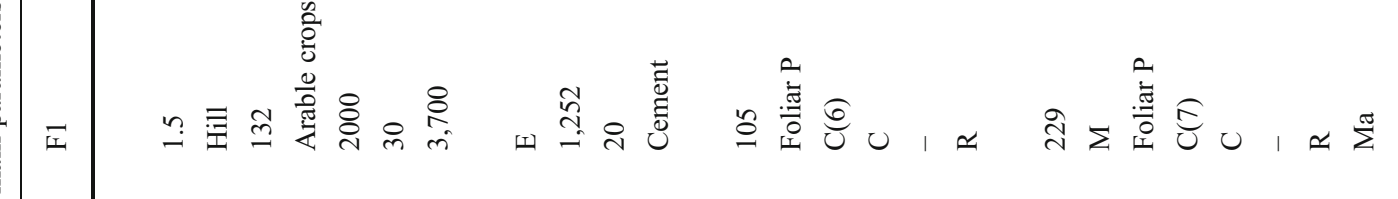

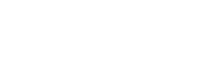


Table 3 Physical and chemical characteristics of the soil at vineyard establishment in each farm

\begin{tabular}{|c|c|c|c|c|c|c|c|c|c|}
\hline & $\mathrm{F} 1$ & $\mathrm{~F} 2$ & F3 & $\mathrm{F} 4$ & F5 & F6 & F7 & F8 & F9 \\
\hline \multicolumn{10}{|l|}{ Physical } \\
\hline Sand $\left(\mathrm{g} \mathrm{kg}^{-1}\right)$ & 200 & 325 & 511 & 799 & 450 & 569 & 325 & 475 & 774 \\
\hline Silt $\left(\mathrm{g} \mathrm{kg}^{-1}\right)$ & 485 & 216 & 202 & 119 & 360 & 246 & 216 & 335 & 124 \\
\hline Clay $\left(\mathrm{g} \mathrm{kg}^{-1}\right)$ & 315 & 459 & 287 & 81 & 190 & 185 & 459 & 190 & 102 \\
\hline Texture & Clay loam & Clay & Sandy clay loam & Loamy sand & Loam & Sandy loam & Clay & Loam & Sandy loam \\
\hline Coarse fragments $(\%)$ & 0.00 & 0.00 & 0.00 & 5.57 & 0.00 & 2.00 & 0.00 & 0.00 & 0.00 \\
\hline Bulk density $\left(\mathrm{g} \mathrm{cm}^{-3}\right)$ & 1.30 & 1.31 & 1.40 & 1.62 & 1.42 & 1.45 & 1.31 & 1.52 & 1.52 \\
\hline \multicolumn{10}{|l|}{ Chemical } \\
\hline $\mathrm{pH}$ & - & - & 6.92 & 6.95 & - & 6.24 & - & - & 7.28 \\
\hline Limestone $\left(\mathrm{g} \mathrm{kg}^{-1}\right)$ & 0.00 & 0.00 & 1.53 & 6.20 & 0.00 & 0.00 & 0.00 & 0.01 & 0.01 \\
\hline $\begin{array}{l}\text { Soil organic matter } \\
\left(\mathrm{g} \mathrm{kg}^{-1}\right)\end{array}$ & 11.90 & 19.90 & 18.60 & 13.70 & 11.90 & 13.70 & 18.60 & 15.80 & 19.00 \\
\hline Total $\mathrm{N}\left(\mathrm{g} \mathrm{kg}^{-1}\right)$ & - & - & 1.12 & 0.60 & - & 0.75 & - & - & 0.90 \\
\hline Available $\mathrm{P}\left(\mathrm{mg} \mathrm{kg}^{-1}\right)$ & - & - & 243.83 & 129.67 & - & 118.20 & 130.00 & - & 124.00 \\
\hline $\begin{array}{l}\text { Exchangeable } \mathrm{K} \\
\left(\mathrm{mg} \mathrm{kg}^{-1}\right)\end{array}$ & - & - & 394.25 & - & - & $1,520.30$ & $5,838.00$ & - & 701.00 \\
\hline
\end{tabular}

questionnaires, while data relating to the physical and chemical characteristics of the soil were provided by farmers in the form of soil samples collected at the vineyard planting stage (see Table 3).

Table 5 reports the vineyard management technique in place and the operations directly influencing soil management for each agricultural sub-phase.

\subsection{Scenarios, sensitivity analysis and Monte Carlo analysis}

A sensitivity analysis was performed to evaluate the robustness of the LCA model and to identify the key parameters. This analysis particularly focussed on the main factors of SOM balance to evaluate the role of soil in the overall CF. A variation of $\pm 20 \%$ from baseline values was applied across all of the main parameters, while for $\mathrm{N}_{2} \mathrm{O}$ emissions a variation of $\pm 70 \%$ was applied, given the uncertainty in emission factors, as suggested by the IPCC (2006). Overall model uncertainty was quantified using Monte Carlo analysis. The uncertainty value in primary data for the SOM model was set to equal the uncertainty observed in real-life farm-level data, with 10,000 iterations.

Four scenarios were created for SOM change to assess the impact of the different vineyard soil management techniques at all farms. For this study, we assumed that the soil management techniques would not affect the grape yield, fixed at $9 \mathrm{Mg} \mathrm{ha}^{-1}$ year ${ }^{-1}$ by the DOCG regulatory board. The current soil management technique used at each farm was taken as the baseline, both with (B2) and without (B1) soil inclusion. The four scenarios were as follows, with decreasing levels of OM inputs:
- S1: manure distribution at vineyard planting, inter-row grassing with cover crops, incorporation of pruning residues into the soil

- S2: no manure distribution, inter-row grassing with cover crops, incorporation of pruning residues into the soil

- S3: manure at vineyard planting, tillage for weed control, pruning residues removed

- S4: no manure distribution, tillage for weed control, pruning residues removed

The four scenarios were developed to understand impacts of choosing one common vineyard soil management for all the winery farms and the range of variation in soil emissions between the best and the worst cases.

Table 6 shows the parameter values of the baseline with soil inclusion (B2) and the four scenarios.

\section{Results}

\subsection{Wine carbon footprint}

SOM accounting reduced the mean production impact per bottle of wine by $20 \%$, lowering net mean emissions from 0.663 to $0.531 \mathrm{~kg} \mathrm{CO}_{2}$-eq (Fig. 3). SOM accounting did not affect the winery phase, which stood at $0.543 \mathrm{~kg} \mathrm{CO}_{2}$ eq/FU, but had strong impacts on the vineyard phase, lowering mean emissions from 0.120 to $-0.011 \mathrm{~kg} \mathrm{CO}_{2}$-eq/FU. This is the result of a slight increase in the mean SOM pool during the vineyard cultivation life cycle. Thus, overall the 


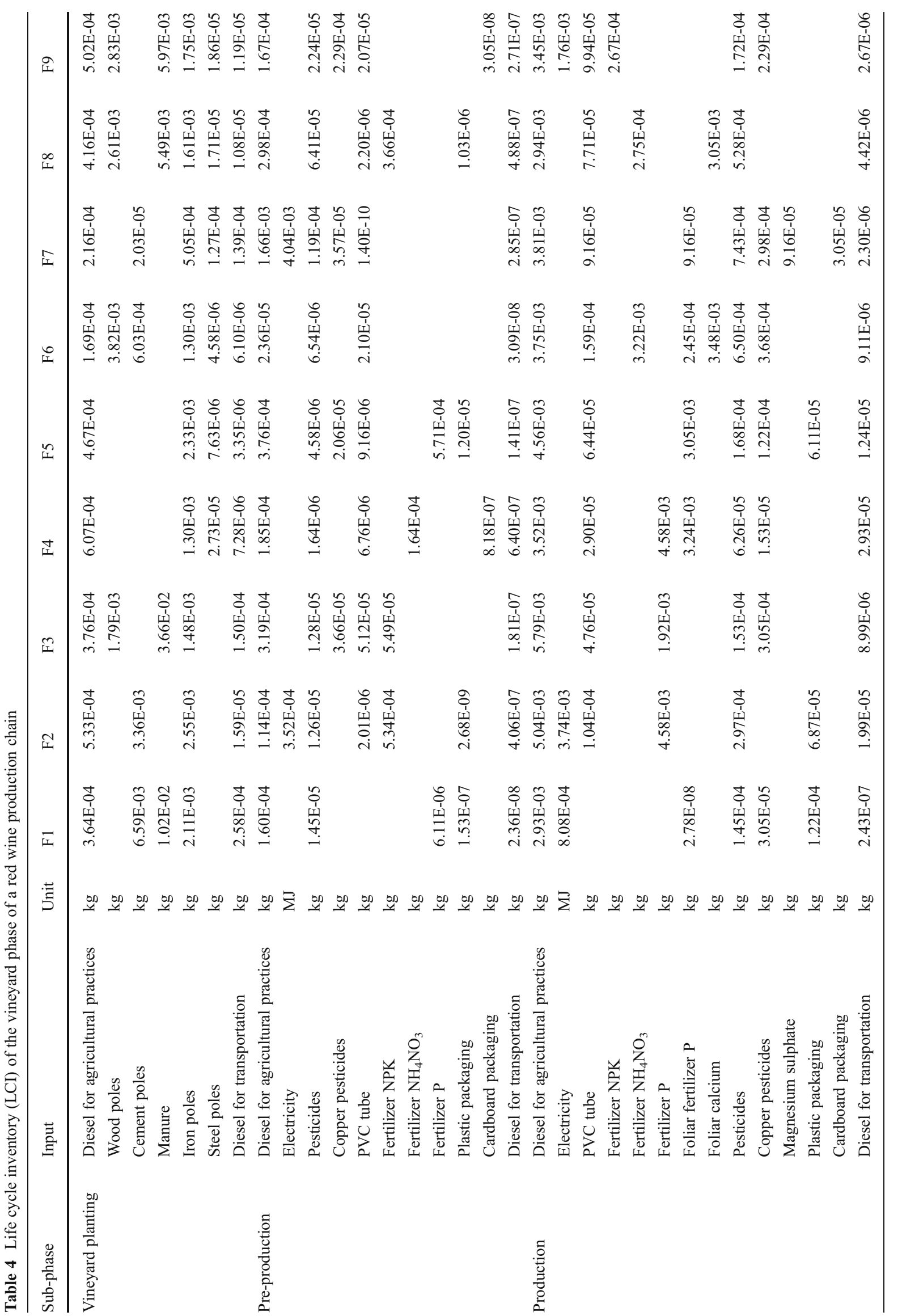


Table 5 Life cycle inventory (LCI) of the winery phase of a red wine production chain

\begin{tabular}{|c|c|c|c|}
\hline Sub-phase & Input & Unit & Value \\
\hline \multirow[t]{12}{*}{ Vinification } & Electricity & MJ & $4.40 \mathrm{E}-01$ \\
\hline & Diesel for transportation & $\mathrm{kg}$ & $1.61 \mathrm{E}-06$ \\
\hline & Grapes & $\mathrm{kg}$ & $1.24 \mathrm{E}+00$ \\
\hline & Potassium metabisulphite & $\mathrm{kg}$ & $1.07 \mathrm{E}-04$ \\
\hline & Detergents & $\mathrm{kg}$ & $3.71 \mathrm{E}-04$ \\
\hline & Plastic packaging & $\mathrm{kg}$ & 4.12E-05 \\
\hline & Pectolytic enzymes & $\mathrm{m}^{3}$ & $1.24 \mathrm{E}-05$ \\
\hline & Yeasts & $\mathrm{kg}$ & $3.21 \mathrm{E}-04$ \\
\hline & Pomace & $\mathrm{kg}$ & $6.18 \mathrm{E}-02$ \\
\hline & Stalk & $\mathrm{kg}$ & $2.06 \mathrm{E}-02$ \\
\hline & Pips, skins & $\mathrm{kg}$ & $2.88 \mathrm{E}-01$ \\
\hline & Wine & $\mathrm{m}^{3}$ & $7.50 \mathrm{E}-04$ \\
\hline \multirow[t]{4}{*}{ Bottling } & Electricity & MJ & $1.05 \mathrm{E}-01$ \\
\hline & Diesel for transportation & $\mathrm{kg}$ & $9.54 \mathrm{E}-06$ \\
\hline & Wine & $\mathrm{m}^{3}$ & $7.50 \mathrm{E}-04$ \\
\hline & Plastic packaging & $\mathrm{kg}$ & $1.99 \mathrm{E}-04$ \\
\hline \multirow[t]{7}{*}{ Packaging } & Electricity & MJ & $1.66 \mathrm{E}-02$ \\
\hline & Diesel for transportation & $\mathrm{kg}$ & 7.39E-03 \\
\hline & Glass bottle & $\mathrm{kg}$ & 4.10E-01 \\
\hline & Cork & $\mathrm{kg}$ & $6.00 \mathrm{E}-03$ \\
\hline & Capsule & $\mathrm{kg}$ & $2.00 \mathrm{E}-03$ \\
\hline & Label & $\mathrm{kg}$ & $5.00 \mathrm{E}-03$ \\
\hline & Cardboard packaging & $\mathrm{kg}$ & $5.48 \mathrm{E}-02$ \\
\hline Distribution & Diesel for transportation & $\mathrm{kg}$ & $2.45 \mathrm{E}-02$ \\
\hline \multirow[t]{4}{*}{ Waste management } & Glass bottle & $\mathrm{kg}$ & 4.10E-01 \\
\hline & Capsule & $\mathrm{kg}$ & $2.00 \mathrm{E}-03$ \\
\hline & Label & $\mathrm{kg}$ & $5.00 \mathrm{E}-03$ \\
\hline & Cork & $\mathrm{kg}$ & $6.00 \mathrm{E}-03$ \\
\hline
\end{tabular}

result for the vineyard phase was a net reduction in $\mathrm{CO}_{2}$ emissions (see Fig. 3).

\subsection{Vineyard phase and soil organic matter balance}

Emissions from the vineyard phase exhibited high variability among the nine farms. In four of the farms, inclusion of SOM reduced net GHG emissions compared to the baseline (B1) value, while in five farms these emissions were increased (Fig. 4a). Farms F2 and F8 had the highest emissions, with a mean value twofold higher than the value obtained without soil inclusion (B1). The best result was obtained in F3, whose mean emissions decreased from 0.012 to $-0.036 \mathrm{~kg} \mathrm{CO}_{2}$-eq/FU (see Fig. 4a).

The observed variability was strongly affected by vineyard soil management. For B2, vineyard planting was one of the main sources of GHG emissions across all farms, both for emissions deriving from diesel consumption during soil
Table 6 Scenario parameters description

\begin{tabular}{|c|c|c|c|c|c|c|}
\hline Farms & Parameters & B2 & $\mathrm{S} 1$ & S2 & S3 & S4 \\
\hline $\mathrm{F} 1$ & \multirow[t]{9}{*}{ Manure (Mg f.m.ha ${ }^{-1}$ ) } & 20 & 65 & 0 & 65 & 0 \\
\hline $\mathrm{F} 2$ & & 0 & 65 & 0 & 65 & 0 \\
\hline $\mathrm{F} 3$ & & 65 & 65 & 0 & 65 & 0 \\
\hline $\mathrm{F} 4$ & & 0 & 65 & 0 & 65 & 0 \\
\hline F5 & & 0 & 65 & 0 & 65 & 0 \\
\hline F6 & & 0 & 65 & 0 & 65 & 0 \\
\hline F7 & & 0 & 65 & 0 & 65 & 0 \\
\hline F8 & & 9 & 65 & 0 & 65 & 0 \\
\hline F9 & & 10 & 65 & 0 & 65 & 0 \\
\hline F1 & \multirow[t]{9}{*}{ Grassing (Mg d.m.ha ${ }^{-1}$ ) } & 0 & 4.5 & 4.5 & 0 & 0 \\
\hline $\mathrm{F} 2$ & & 0 & 4.5 & 4.5 & 0 & 0 \\
\hline F3 & & 4.5 & 4.5 & 4.5 & 0 & 0 \\
\hline $\mathrm{F} 4$ & & 0 & 4.5 & 4.5 & 0 & 0 \\
\hline F5 & & 4 & 4.5 & 4.5 & 0 & 0 \\
\hline F6 & & 4 & 4.5 & 4.5 & 0 & 0 \\
\hline F7 & & 4 & 4.5 & 4.5 & 0 & 0 \\
\hline F8 & & 0 & 4.5 & 4.5 & 0 & 0 \\
\hline F9 & & 0 & 4.5 & 4.5 & 0 & 0 \\
\hline $\mathrm{F} 1$ & \multirow[t]{9}{*}{ Residue (Mg f.m.ha ${ }^{-1}$ ) } & 0 & 3.02 & 3.02 & 0 & 0 \\
\hline $\mathrm{F} 2$ & & 0 & 3.02 & 3.02 & 0 & 0 \\
\hline $\mathrm{F} 3$ & & 3.02 & 3.02 & 3.02 & 0 & 0 \\
\hline F4 & & 3.02 & 3.02 & 3.02 & 0 & 0 \\
\hline F5 & & 3.02 & 3.02 & 3.02 & 0 & 0 \\
\hline F6 & & 3.02 & 3.02 & 3.02 & 0 & 0 \\
\hline F7 & & 3.02 & 3.02 & 3.02 & 0 & 0 \\
\hline F8 & & 0 & 3.02 & 3.02 & 0 & 0 \\
\hline F9 & & 3.02 & 3.02 & 3.02 & 0 & 0 \\
\hline
\end{tabular}

The organic matter inputs values are reported in mg of dry matter per hectare

preparation and for soil emissions linked to SOM loss due to deep tillage at vineyard establishment (see Fig. 4b).

The results for the pre-production and production subphases were influenced mostly by farm management technique. In cases of non-conservative soil management, characterised by little manure distribution at vineyard establishment, all three sub-phases constituted sources of emissions (F1, F2 and F8). Lower net emissions were observed when pruning residues were incorporated into the soil (F4 and F9), showing a slight reduction in the production subphase. The impact of vineyard soil management was evident in the farms with adequate manure distribution at establishment (65 $\left.\mathrm{Mg} \mathrm{ha}^{-1}\right)$, inter-row grassing and the incorporation of pruning residues and stalks, as seen in F3, F5, F6 and F7. Indeed, these farms showed reductions from the preproduction sub-phase onwards (see Fig. 4b).

Great variability in initial SOM content was detected across the farms (Table 7), ranging from 46.4 in F1 to 88.3 


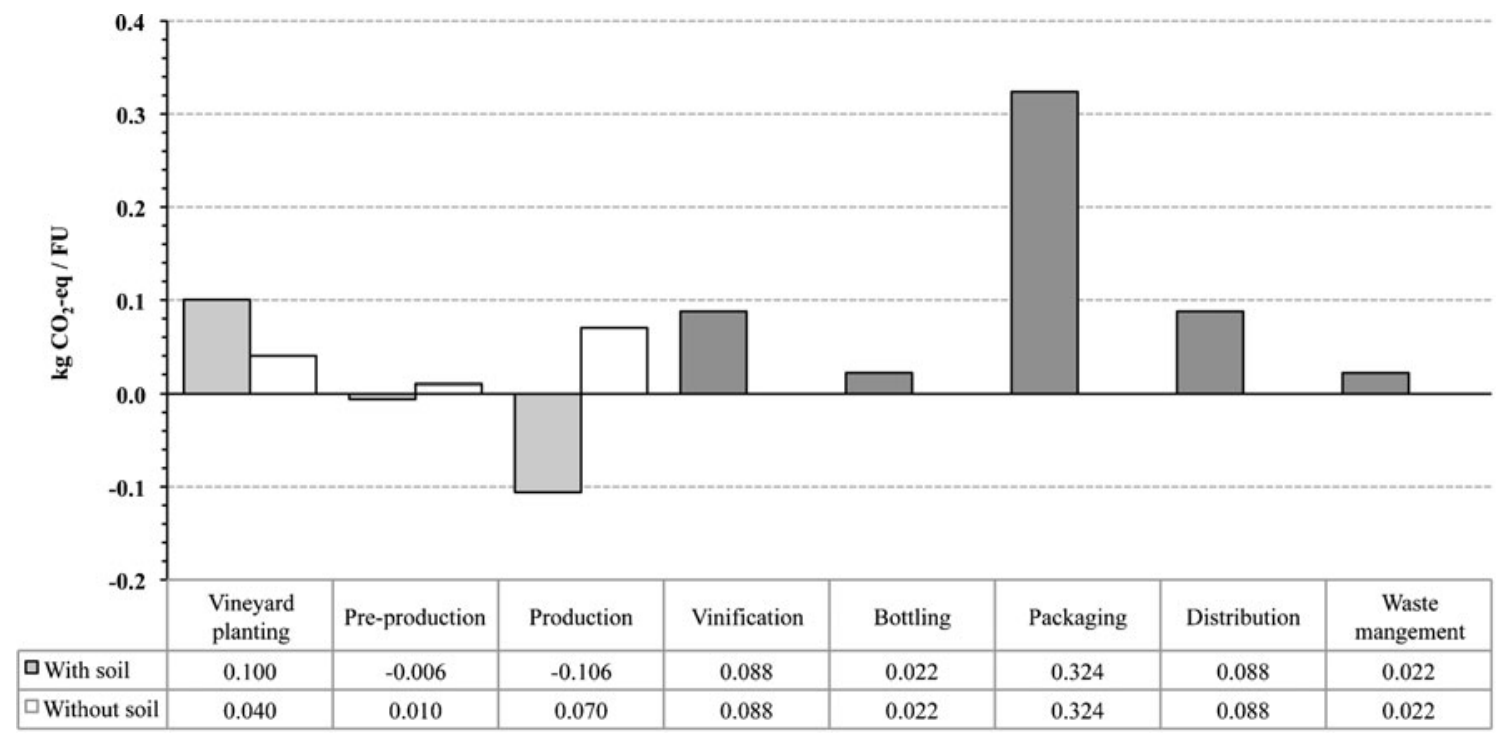

Fig. 3 Carbon footprint of bottled red wine per functional unit (FU) $\left(\mathrm{kg} \mathrm{CO}_{2}\right.$-eq/0.75 L packaged wine) for each sub-phase, with and without $\mathrm{SOM}$ accounting. The vineyard phase shows the mean value of all farms

$\mathrm{Mg} \mathrm{ha}^{-1}$ in F3, the result of site-specific soil characteristics (Fig. 5). In all farms, vineyard planting initially decreased OM (from -1.4 to $-11.6 \%$ in F3 and F9, respectively), followed by a decrease or increase in the SOM pool depending on the soil management practices adopted. The pre-production subphase appeared neutral, without significant absorption or removal, due to the light soil management and low residue production. For the production sub-phase, mean soil management of the nine farms gave a net accumulation of $\mathrm{C}$ in the soil (see Fig. 5). For the overall vineyard lifespan before normalisation, the SOM model predicted a reduction in $\mathrm{SOM}$ in all farms except for $\mathrm{F}$, which sequestered $\mathrm{C}$; after normalisation, F5, F6 and F7 also showed a net $\mathrm{C}$ sequestration (Table 8).

\subsection{Scenario analysis}

The scenarios were established to estimate the effects of different vineyard soil management techniques applied simultaneously across all farms, using manure distribution, residue management and inter-row grassing as variables. Non-conservative soil management doubled agricultural GHG emissions, as in S3 and S4 relative to B1, and soil was often a net source of emissions, with mean increases of $43 \%$ (Fig. 6). Meanwhile, S1 and S2 saw overall emissions reduced by $49 \%$, with net values of 0.251 and $0.295 \mathrm{~kg}$ $\mathrm{CO}_{2}$-eq/FU, respectively.

\subsection{Sensitivity and Monte Carlo analyses}

The sensitivity analysis revealed that the most influential parameters were the mass of the glass bottle and the electricity consumed during the vinification sub-phase, with the winery phase as a whole having the most impact (Table 9). For the vineyard phase, the main parameters were those corresponding to the soil model, in particular, $k_{2}$ and initial SOM concentrations.

The outcomes of the Monte Carlo analysis revealed that uncertainty in the input parameters in the SOM model had a low influence on the wine $\mathrm{CF}$. The $95 \%$ confidence interval of the wine $\mathrm{CF}$ fell between 0.507 and $0.544 \mathrm{~kg} \mathrm{CO}_{2}$-eq/FU. Indeed, the Monte Carlo analysis showed a range of uncertainty from -4.5 to $2.5 \%$, with an average value of $1.49 \%$.

\section{Discussion}

\subsection{Wine carbon footprint}

The GWP of a $0.75-\mathrm{L}$ bottle of red wine, excluding SOM changes, was equal to $0.663 \mathrm{~kg} \mathrm{CO}_{2}$-eq, which is comparable to results obtained in previous studies (Notarnicola et al. 2003; Point 2008; Gazulla et al. 2010). In contrast, Ardente et al. (2006) reported a GWP value twice as high, due to the inclusion of biogenic $\mathrm{CO}_{2}$ emissions from grape fermentation. The most impactful sub-phases in the wine production chain are found in the winery phase, accordingly to the literature, while the vineyard phase represents about $22 \%$ of the overall impact (Notarnicola et al. 2003; Gazulla et al. 2010; Soja et al. 2010; Bosco et al. 2011; Colman and Päster 2009).

In our study, including SOM changes reduced the GWP of a 0.75 -L bottle of red wine by approximately $20 \%$. The main source of emissions can still be attributed to the winery phase ( $84 \%$ ), but the second source was the vineyard planting subphase $(16 \%)$, due to the emissions released during soil 
a

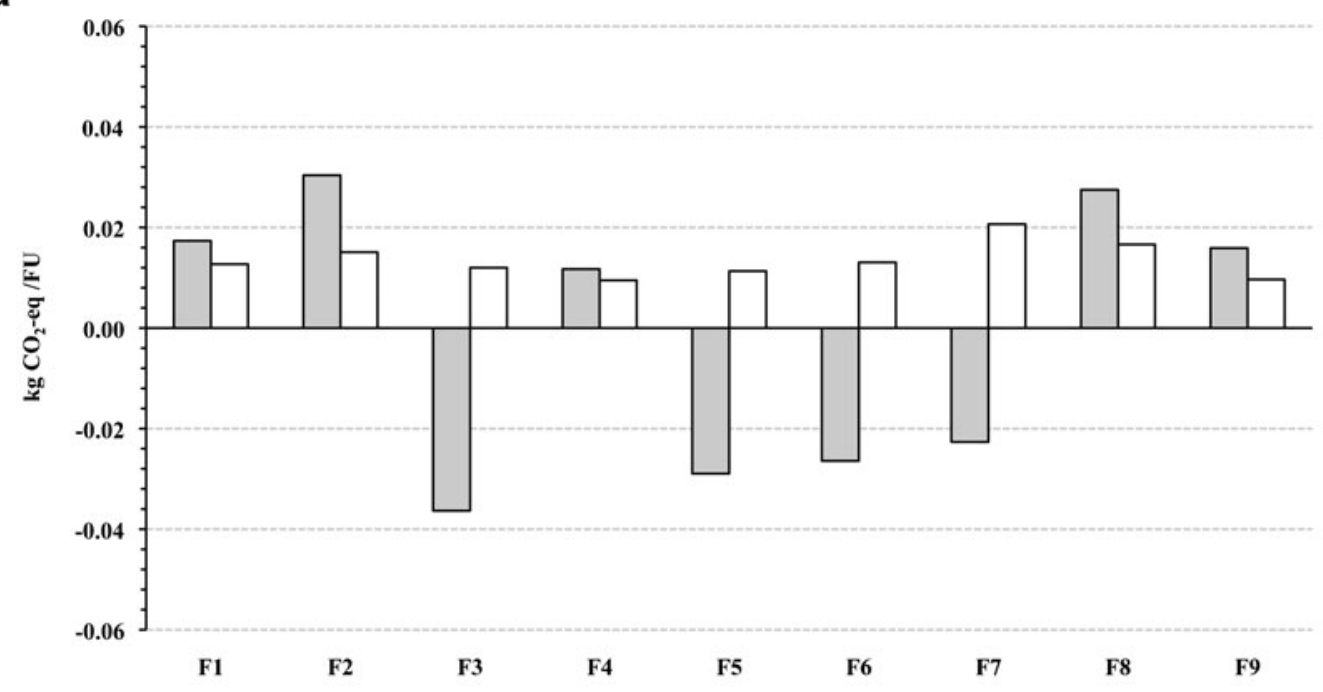

b

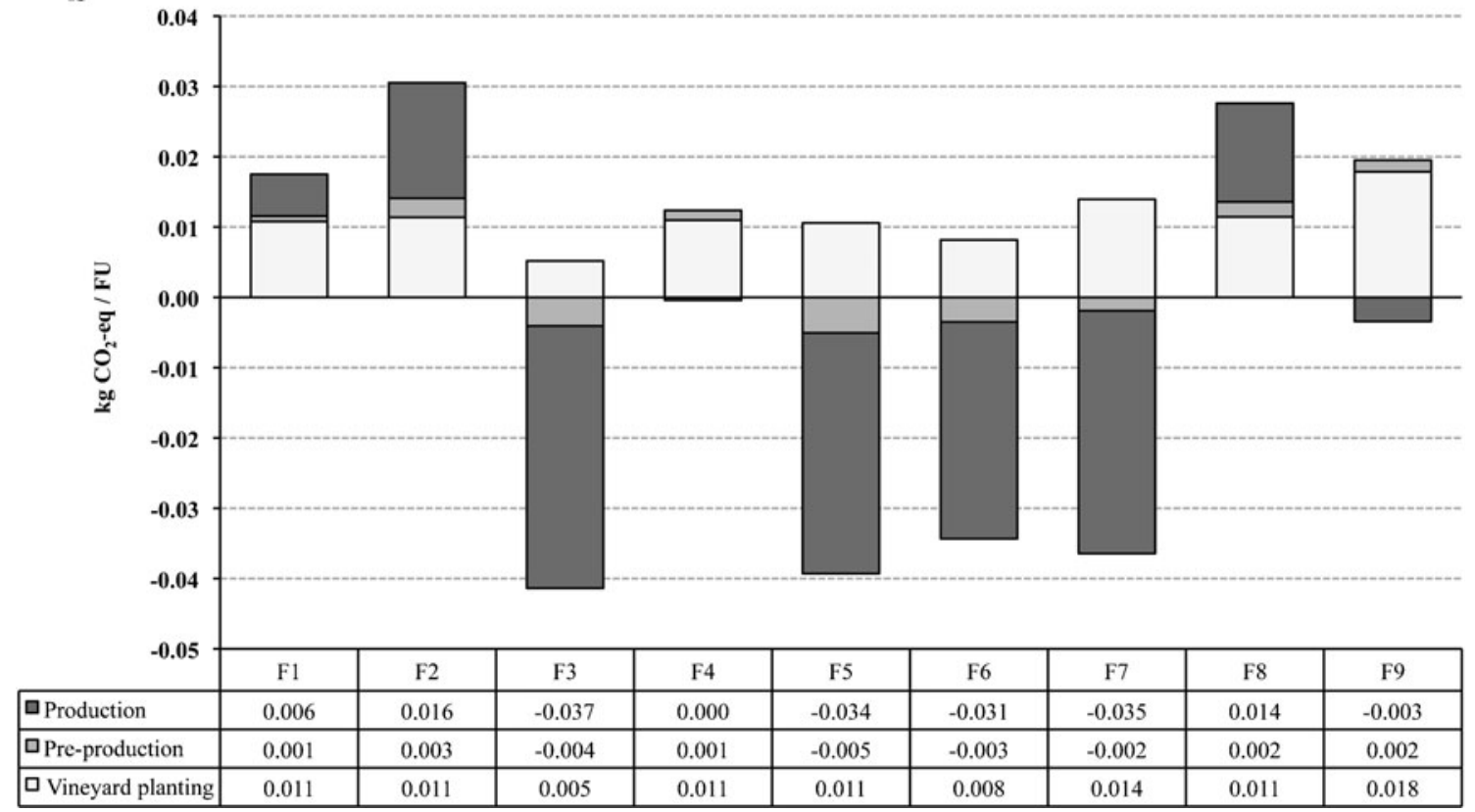

Fig. 4 Detailed global warming potential per functional unit of a the vineyard phase of each farm, with and without soil inclusion (kg $\mathrm{CO}_{2}$-eq/ $0.75 \mathrm{~L}$ packed wine) and $\mathbf{b}$ each vineyard sub-phase and farm including soil $\left(\mathrm{kg} \mathrm{CO}_{2}\right.$-eq $/ 0.75 \mathrm{~L}$ packaged wine)

preparation. The pre-production and production sub-phases accounted for 5 and $95 \%$ of overall reduction, respectively.

\subsection{SOM change accounting for soil management}

The model we proposed included OM inputs into the soil and SOM losses due to natural and cultivation-induced mineralisation in permanently cultivated vineyard soils. Land use did not change during the period of study, and the only factor driving changes in SOM was soil management.

The model used in this study revealed the positive impact of cover crops on SOM content, as an alternative to the use of inter- row harrowing for weed control (Parat et al. 2002; Steenwerth and Belina 2008). Focussing on the pre-production and production sub-phases, farms that included natural grassing or cover crops and incorporated residues into the soil (F3, F5, F6, F7) had lower net GWP than farms that solely applied manure during the vineyard planting sub-phase (F1, F8). F2 had higher net GWP, where grassing was replaced with harrowing for weed control and pruning residues were removed from the field (see Table 8). The impacts of these operations led to a significant decrease in OM inputs into the soil and, consequently, to SOM pool imbalance in favour of mineralisation. In our study, mean soil carbon sequestration stood at $-5 \mathrm{~g} \mathrm{C} \mathrm{m}^{-2}$ year $^{-1}$, ranging 
Table 7 Details for each farm of the initial soil organic matter pool $\left(\mathrm{Mg} \mathrm{ha}^{-1}\right)$, organic matter inputs and outputs and final SOM (Mg ha $\left.{ }^{-1}\right)$ for each vineyard sub-phase

\begin{tabular}{|c|c|c|c|c|c|c|c|c|c|c|}
\hline \multirow[t]{2}{*}{ Farms } & \multirow[b]{2}{*}{$\begin{array}{l}\text { Initial } \\
\text { SOM }\end{array}$} & \multicolumn{3}{|c|}{ Vineyard planting } & \multicolumn{3}{|c|}{ Pre-production phase } & \multicolumn{3}{|c|}{ Production phase } \\
\hline & & $\begin{array}{l}\text { OM } \\
\text { input }\end{array}$ & $\begin{array}{l}\text { OM } \\
\text { output }\end{array}$ & $\begin{array}{l}\text { Final } \\
\text { SOM }\end{array}$ & $\begin{array}{l}\text { OM } \\
\text { input }\end{array}$ & $\begin{array}{l}\text { OM } \\
\text { output }\end{array}$ & $\begin{array}{l}\text { Final } \\
\text { SOM }\end{array}$ & $\begin{array}{l}\text { OM } \\
\text { input }\end{array}$ & $\begin{array}{l}\text { OM } \\
\text { output }\end{array}$ & $\begin{array}{l}\text { Final } \\
\text { SOM }\end{array}$ \\
\hline $\mathrm{F} 1$ & 46.41 & 1.56 & 2.59 & 45.38 & 0.40 & 0.58 & 45.20 & 0.48 & 0.58 & 45.10 \\
\hline $\mathrm{F} 2$ & 78.46 & 0.36 & 4.19 & 74.63 & 0.40 & 0.75 & 74.28 & 0.40 & 0.74 & 73.94 \\
\hline F3 & 88.30 & 4.26 & 5.53 & 87.04 & 1.72 & 0.51 & 88.25 & 2.10 & 0.52 & 89.83 \\
\hline $\mathrm{F} 4$ & 66.42 & 0.36 & 7.61 & 59.17 & 1.00 & 1.16 & 59.01 & 1.38 & 1.15 & 59.25 \\
\hline F5 & 50.69 & 0.36 & 4.25 & 46.80 & 1.60 & 0.48 & 47.92 & 1.98 & 0.49 & 49.41 \\
\hline F6 & 53.84 & 0.36 & 4.92 & 49.28 & 1.60 & 0.55 & 50.33 & 1.98 & 0.56 & 51.75 \\
\hline F7 & 73.10 & 0.36 & 3.89 & 69.56 & 1.60 & 0.45 & 70.71 & 1.98 & 0.46 & 72.23 \\
\hline F8 & 72.05 & 0.90 & 7.09 & 65.85 & 0.40 & 0.56 & 65.70 & 0.48 & 0.56 & 65.62 \\
\hline F9 & 86.48 & 0.96 & 10.98 & 76.47 & 1.00 & 1.09 & 76.38 & 1.38 & 1.09 & 76.67 \\
\hline
\end{tabular}

The initial SOM before the vineyard planting and OM input values were measured, while the OM output and the final SOM values were estimated by the Hénin-Dupuìs model before the normalisation

from $-16 \mathrm{~g} \mathrm{C} \mathrm{m}^{-2}$ year ${ }^{-1}$ in $\mathrm{F} 3$ to $5 \mathrm{~g} \mathrm{C} \mathrm{m}^{-2}$ year $^{-1}$ in $\mathrm{F} 2$. Our results were comparable to the value of $-15 \mathrm{~g} \mathrm{C} \mathrm{m}^{-2}$ year $^{-1}$ observed in a long-term study (30 years) conducted in a Californian Mediterranean climate (Kroodsma and Field 2006). To the best of our knowledge there is only one limited LCA of wine that includes soil as a factor (Soja et al. 2010), and it provides no information on the contribution of soil to the overall $\mathrm{CF}$. The main recent studies on the inclusion of soil models in LCA (Milà i Canals et al. 2007; Brandão et al. 2011) considered SOM variations in the case of changes in land use over the long-term, using the RothC model and soil carbon stock changes. As regards GHG emission reduction in organic and conventional agricultural product LCAs, Meisterling et al. (2009) assumed the same value for soil carbon sequestration in wheat for both systems. In their sensitivity analysis, using literature data, they adopted a sequestration rate of $0-1,700 \mathrm{~kg}$ $\mathrm{CO}_{2}$-eq $\mathrm{ha}^{-1}$ year $^{-1}$ for organic systems and $0-1,100 \mathrm{~kg}$ $\mathrm{CO}_{2}$-eq ha ${ }^{-1}$ year $^{-1}$ for conventional systems, which revealed net emissions equal to $250 \mathrm{~kg} \mathrm{CO}_{2}$-eq ha ${ }^{-1}$ year $^{-1}$, resulting from tillage practices. Nevertheless, it necessary to point out that the data were collected from nine farms in the same area for 1 year. It would be interesting to test the model on a broader group of farms and in other environments.

\subsection{Scenario analysis and vineyard soil management}

The scenarios developed allowed us to understand the influence of different vineyard soil management practices

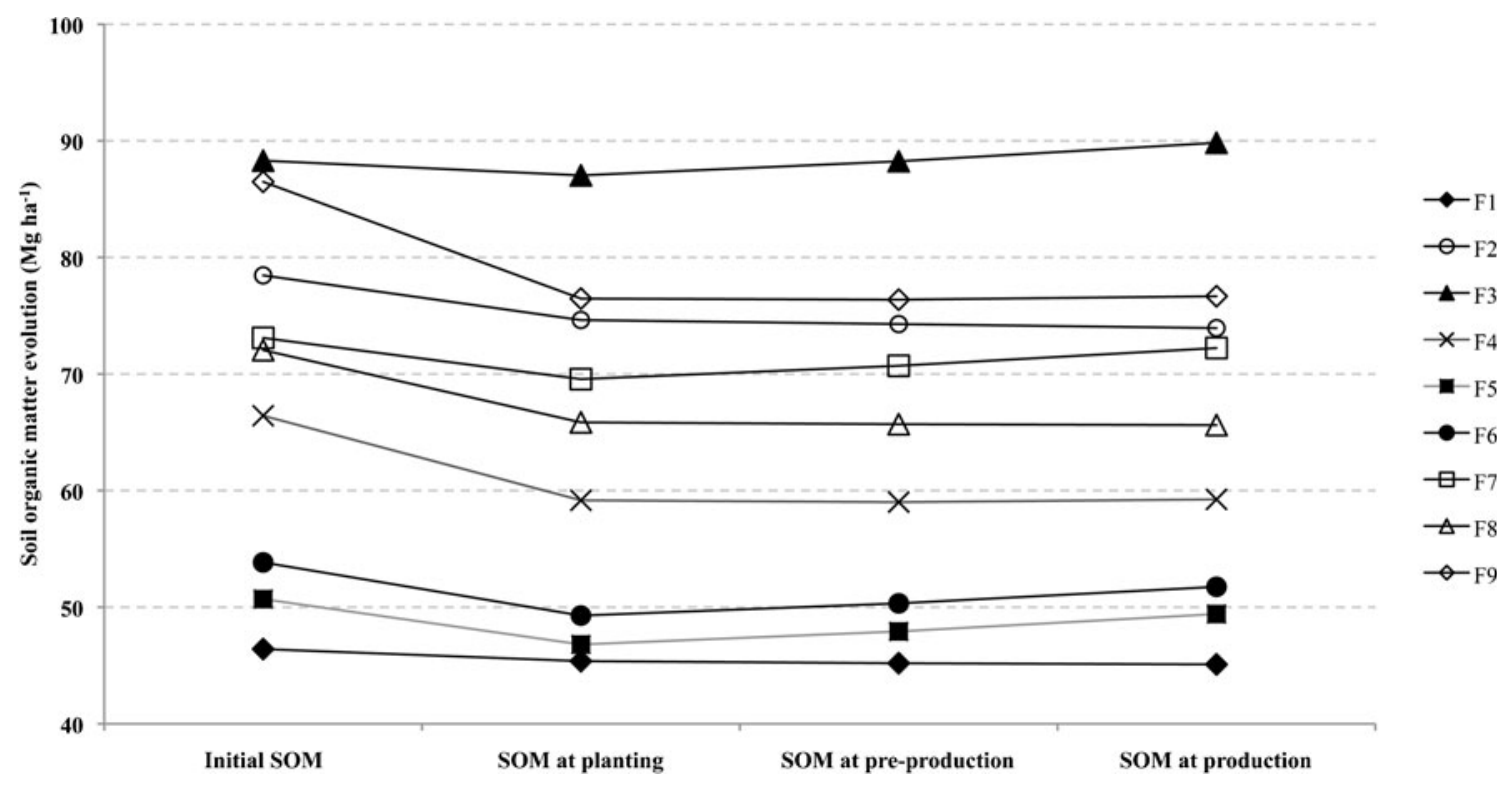

Fig. 5 Soil organic matter (SOM) change over the vineyard lifetime estimated by the Hénin-Dupuis model for each farm 
applied simultaneously across all farms. S1 saw emissions halved compared to B2, and similar results were observed inS2, where residue incorporation and grassing were used. These practices were identified as the main factors affecting SOM change in vineyard soil, as also reported by Steenwerth and Belina (2008). Both inter-row grassing with cover crops and the incorporation of pruning residues into the soil helped increase the rate of carbon sequestration and, despite a small increase in direct $\mathrm{N}_{2} \mathrm{O}$ emissions, reduce net $\mathrm{GHG}$ emissions. In addition, the practice of inter-row grassing can decrease nitrogen $(\mathrm{N})$ leaching and the rate of soil erosion (Carlisle et al. 2010).

As reported by many authors, organic fertilisers such as manure can increase SOM content in vineyards (Morlat and Chaussod 2008; Coll et al. 2011). Nevertheless, a single application of manure at vineyard planting (S3), even in optimal amounts for local environmental characteristics (in this case, $65 \mathrm{Mg} \mathrm{ha}^{-1}$ year $^{-1}$ ), was not by itself able to balance out SOM losses due to natural and cultivation-induced mineralisation. A better management solution for manure might be its distribution every 5-10 years during the vineyard lifespan (Fregoni 1989), although GHG emissions for manure transport might also be increased as a consequence.

The worst-case scenario (S4), without any direct supply of OM inputs into the soil, led to net emissions increasing by more than $50 \%$ compared to B2. In addition this management technique can have negative consequences for maintenance of soil fertility and SOM content. Moreover, S4 showed that the inclusion of soil in the LCA of agricultural products and systems does not always result in $\mathrm{CO}_{2}$ absorption. In fact, the mitigation potential of agriculture is linked to the soil's carbon sequestration capacity, which correlates strongly with the management practices adopted (Smith et al. 2008). It has to be highlighted that only soil management was integrated in the vineyard management techniques; certain excluded techniques could differ between farms and modify the $\mathrm{CF}$.

\subsection{Sensitivity and uncertainty analyses}

The mass of the glass bottle was the most important parameter influencing the final results, in agreement with the literature on wine chain LCAs (Notarnicola et al. 2003; Gazulla et al. 2010). For the vineyard phase, the main influential parameters were related to the amount of OM inputs (cover crops, residues) and the mineralisation and humification coefficients.

Most studies recognise $\mathrm{N}_{2} \mathrm{O}$ emissions as an important source of GHG in agricultural products (Meisterling et al. 2009; Roy et al. 2009; Röös et al. 2000). It is also wellknown that $\mathrm{N}_{2} \mathrm{O}$ emissions directly correlate with the rate of $\mathrm{N}$ application to soil (IPCC 2006; Hillier et al. 2009). In this study, $\mathrm{N}_{2} \mathrm{O}$ emissions from $\mathrm{N}$ fertiliser applications were not deemed relevant, due to the rich natural $\mathrm{N}$ content of the soil 


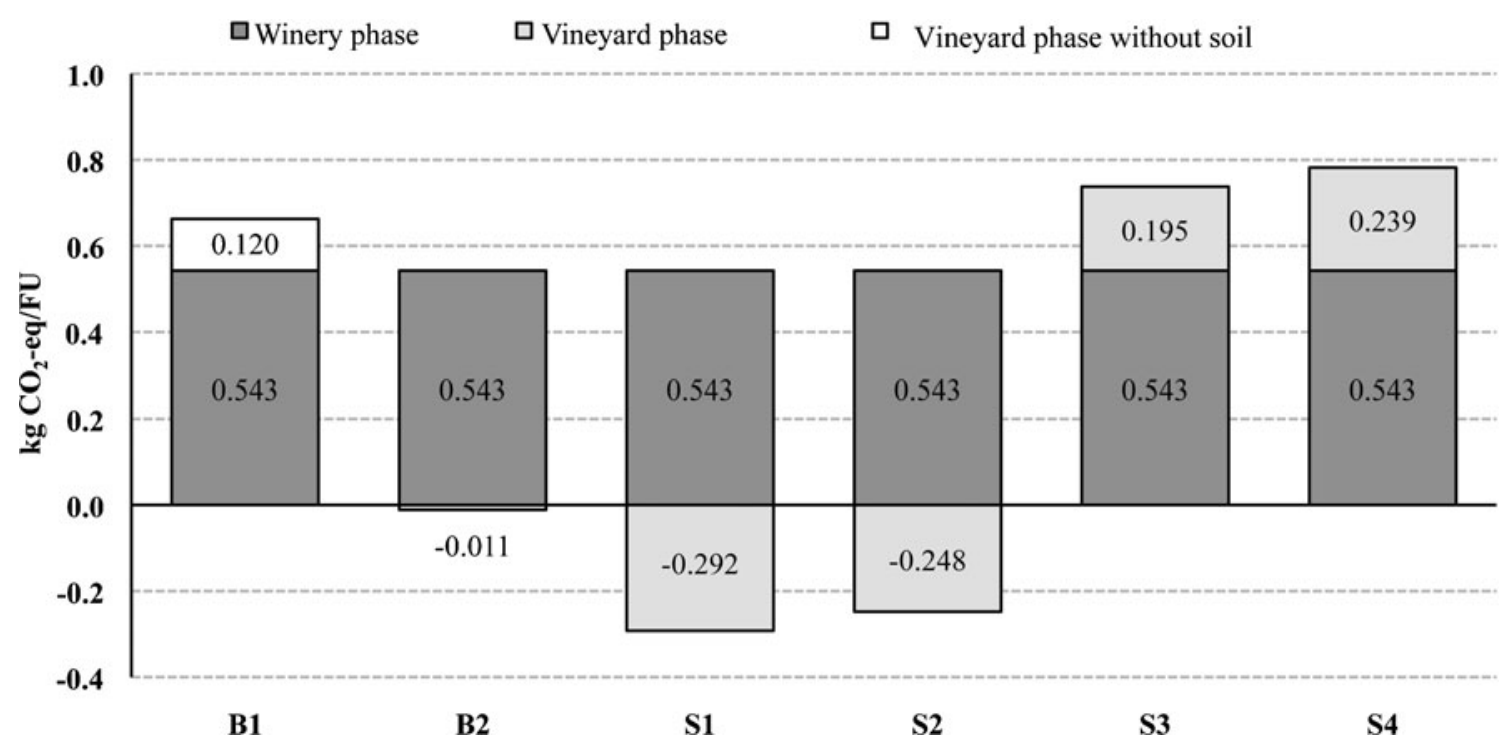

Fig. 6 Scenario analysis. The four scenarios considered for comparing vineyard soil management outcomes using the mean value of all farms vs. the baseline without soil (B1) and with soil (B2), were: scenario 1 (S1 manure distribution at vineyard planting; inter-row grassing with cover crops; incorporation of pruning residues into the soil); scenario 2

at the sample farms, which limited the use of $\mathrm{N}$ fertilisers, applied directly as a foliar spray.

Monte Carlo analysis results showed that the slightly negative mean value of the vineyard phase in B2 still remains negative once uncertainty in inputs has been included $\left(-0.011 \pm 0.008 \mathrm{~kg} \mathrm{CO}_{2}-\mathrm{eq} / \mathrm{FU}\right)$. However, this analysis did not take into account the greater uncertainty related to climate variability, since the SOM model was run on a yearly time step using annual mean temperature.

\section{Conclusions}

In this study we assessed the influence of the inclusion of $\mathrm{SOM}$ balance into the wine chain $\mathrm{CF}$ and the mitigation

Table 9 Sensitivity analysis of individual parameters (\%)

\begin{tabular}{ll}
\hline & Sensitivity analysis (\%) \\
\hline Bottle weight & \pm 9.2 \\
Electricity in vinification & \pm 3.3 \\
Initial organic matter & \pm 6.7 \\
Residues & \pm 4.8 \\
Grass cover & \pm 4.2 \\
Grape yield & \pm 3.7 \\
Fertilisers & \pm 0.3 \\
Manure & \pm 0.3 \\
$k_{2}$ & \pm 6.7 \\
$\mathrm{~N}_{2} \mathrm{O}$ emissions from soil & \pm 0.7 \\
\hline
\end{tabular}

A variation by $\pm 20 \%$ from their baseline values was applied
(S2 no manure distribution; inter-row grassing with cover crops; incorporation of pruning residues into the soil); scenario 3 (S3 manure at vineyard planting; tillage for weed control; pruning residues removed); scenario 4 (S4 no manure distribution; tillage for weed control; pruning residues removed)

potential of soil management. For the first time we evaluated changes in SOM within the same land use in a wine CF, focussing on the impacts of different vineyard soil management practices. With this approach we sought to satisfy the need to integrate a soil carbon dynamics model into agricultural product LCA; we chose the Hénin-Dupuis method, which considered the main variables of SOM dynamics and used measured data. Although best practices for the conservation of soil fertility and SOM content are well-known by academics and policymakers alike, their quantification is difficult and as yet relatively under researched. This is why we investigated the impact of these practices on soil fertility and SOM conservation in our scenario analysis, revealing that the inclusion or exclusion of SOM changes in the analysis of the wine production chain play a crucial role in overall results. Moreover, by using this model to predict SOM change, we were able to identify a minimum data set (MDS) for agricultural product LCAs that accounts for soil carbon, thus establishing a standard for inventory. This MDS includes the following: physical and chemical soil characteristics (clay, SOM and limestone contents), climate parameters (average annual temperature), $\mathrm{OM}$ inputs and management practices.

Our results, albeit limited to data from 1 year for a few farms in the same area, showed that the incorporation of SOM changes into the wine chain $\mathrm{CF}$ saw the role of the vineyard phase change from a GHG source in B1 $(0.120 \mathrm{~kg}$ $\mathrm{CO}_{2}$-eq $\left./ \mathrm{FU}\right)$ to a modest $\mathrm{GHG}$ sink in $\mathrm{B} 2(-0.011 \pm 0.008 \mathrm{~kg}$ $\mathrm{CO}_{2}$-eq/FU). These results highlighted the need to consider soil in wine $\mathrm{CFs}$. By transferring carbon from the atmosphere into $\mathrm{SOM}$, agricultural soils can actually act as $\mathrm{CO}_{2}$ 
sinks. Moreover, soil constitutes a major C pool in cropland, meaning there is scope for large amounts of $\mathrm{C}$ to be gained or lost from soils as a consequence of management practices.

The method outlined in this study, based on SOM balance, considered both OM input into the soil and OM lost in the form of natural and agriculture-induced mineralisation. This simple and robust model was sensitive to changes in management practices.

The minimum data set identified using this method will help LCA experts establish a standardised methodology for soil carbon accounting, setting limits on the use of values taken from soil sequestration literature, and avoid "greenwashing" about soil's mitigation potential.

\section{Recommendations and perspectives}

The 2013-2020 European Common Agricultural Policy will improve integration of climate change mitigation actions within agricultural policy. Indeed, the European Union recognises soil carbon sequestration as one of Europe's major strategies for mitigation (EC 2009). Despite the introduction of a specific priority to promote transition to a low-carbon agriculture and food economy, including fostering carbon sequestration, no new measure to specifically address this priority has yet been included (Matthews 2011). In the context of the scientific debate on soil quality and SOM accounting, the approach proposed in this study can be regarded as a simplified methodology among other existing methodologies.

Within organic agriculture, part of this approach involves paying attention to soil fertility and maintenance of SOM content. Both organic practices and reduced tillage can increase SOM compared to conventional systems (Drinkwater et al. 1998; Robertson et al. 2000; Meisterling et al. 2009). Furthermore, analysis on a mass or per-product basis can lead to higher impact estimates for organic products because of their lower yields per hectare and the use of mechanical rather than chemical weed-control measures. Nevertheless, the application of the CF to organic systems does not take into account all benefits that come from having an organic system. In this way, incorporating soil into the analysis can lead to a more complete comparison of organic and conventional systems, highlighting a positive role of organic farming in the conservation of soil quality.

Recently, there has been growing interest in the CF of agricultural products, as analysed on a per-product or perhectare basis; since the $\mathrm{CF}$ constitutes an effective indicator for encouraging more climate-friendly behaviour among consumers, it is considered a meaningful tool for the mitigation of GHG emissions from agriculture (Finkbeiner 2009). However, as reported in several studies, using only this indicator instead of several (as in LCA) leads to the potential to miss burden shifting and promote products that do not necessarily have lower overall impacts (Weidema et al. 2008). For this reason, the inclusion of agricultural product or system-related SOM changes should be taken into consideration not only for CF studies, but for LCA studies, along with other related factors such as soil erosion, soil physicochemical degradation, eutrophication and $\mathrm{N}$ leaching (Cowell and Clift 2000; Milà i Canals et al. 2007; Hillier et al. 2009; Brandão et al. 2011).

Finally, the key parameters for SOM accounting, as identified in the minimum data set, should be added to existing inventories for agricultural products (Haas et al. 2000; Mourad et al. 2007). Considering the importance of soil in the $\mathrm{CF}$ of all agricultural products, it would be desirable to include it within the new ISO 14067, on the Carbon Footprint of Products, currently under development.

Acknowledgements We gratefully acknowledge the wine growers for their participation in this project, and for providing us extensive information about their agricultural and wine production systems. This research was funded by the Italian Institute for Foreign Trade and by the local government of the Province of Grosseto, Italy. We thank the reviewers for their thorough review and clear comments which significantly contributed to improving the quality of the paper. Many thanks to Dr. Rachel Spencer for the English revision.

\section{References}

Andren O, Katterer T, Karlsson T (2004) ICBM regional model for estimations of dynamics of agricultural soil carbon pools. Nutr Cycl Agroecosys 70:231-239

Andriulo A, Mary B, Guerif J (1999) Modelling soil carbon dynamics with various cropping sequences on the rolling pampas. Agronomie 19:365-377

Aranda A, Scarpellini S, Zabalza I (2005) Economic and environmental analysis of the wine bottle production in Spain by means of life cycle assessment. Int J Agr Resour Govern Ecol 4:178-191

Ardente F, Beccali G, Cellura M, Marvuglia A (2006) POEMS: a case study of an Italian wine-producing firm. Environ Manage 38:350 364

Avraamides M, Fatta D (2008) Resource consumption and emissions from olive oil production: a life cycle inventory case study in Cyprus. J Clean Prod 16:809-821

Bala A, Raugei M, Benveniste G, Gazulla C, Fullana-i-Palmer P (2010) Simplified tools for global warming potential evaluation: when 'good enough' is best. Int J Life Cycle Assess 15:489498

Bayer C, Lovato T, Dieckow J, Zanatta J, Mielniczuk J (2006) A method for estimating coefficients of soil organic matter dynamics based on long-term experiments. Soil Till Res 91:217-226

Bechini L, Castoldi N (2009) On-farm monitoring of economic and environmental performances of cropping systems: results of a 2-year study at the field scale in northern Italy. Ecol Indic 9: $1096-1113$

Bechini L, Castoldi N, Stein A (2011) Sensitivity to information upscaling of agro-ecological assessments: application to soil organic carbon management. Agr Syst 104:480-490 
Bertora C, Zavattaro L, Sacco D, Monaco S, Grignani C (2009) Soil organic matter dynamics and losses in manured maize-based forage systems. Eur J Agron 30:177-186

Bockstaller C, Girardin P (2003) Mode de Calcul des Indicateurs Agrienvironmentaux de la Methode INDIGO. Version $1.61 \mathrm{du}$ Logiciel. Unpublished INRA Internal Technical Report, Colmar, France

Bockstaller C, Guichard L, Makowski D, Aveline A, Girardin P, Plantureux S (2008) Agri-environmental indicators to assess cropping and farming systems. A review. Agron Sustain Dev 28:139-149

Boiffin J, Keli Zagbahi J, Sebillotte M (1986) Systèmes de culture et statut organique des sols dans le Noyonnais: application du modèle de Hénin-Dupuis. Agronomie 6:437-446

Bosco S, Di Bene C, Galli M, Remorini D, Massai R, Bonari E (2011) Greenhouse gas emissions in the agricultural phase of wine production in the Maremma rural district in Tuscany, Italy. Ita $\mathrm{J}$ Agron 6:93-100

Brandão M, Milà I, Canals L, Clift R (2011) Soil organic carbon changes in the cultivation of energy crops: implications for GHG balances and soil quality for use in LCA. Biomass Bioenerg 35:2323-2336

Brentrup F, Kusters J, Kuhlmann H, Lammel J (2004) Environmental impact assessment of agricultural production systems using the life cycle assessment methodology: I. Theoretical concept of a LCA method tailored to crop production. Eur J Agron 20:265279

BSI (2008) PAS 2050:2008 - specification for the assessment of the life cycle greenhouse gas emissions of goods and services. BSI British Standards, London

BSI (2011) PAS 2050:2011—specification for the assessment of the life cycle greenhouse gas emissions of goods and services. BSI British Standards, London

Carlisle E, Smart D, Williams LE, Summers M (2010) California vineyard greenhouse gas emissions: assessment of the available literature and determination of research needs. California Sustainable Winegrowing Alliance. California, p 51, www. sustainablewinegrowing.org

Coll P, Le Cadre E, Blanchart E, Hinsinger P, Villenave C (2011) Organic viticulture and soil quality: a long-term study in Southern France. Appl Soil Ecol 50:37-44

Colman T, Päster P (2009) Red, white, and 'green': the cost of greenhouse gas emissions in the global wine trade. Journal of Wine Research 20:15-26

Cowell SJ, Clift R (1997) Impact assessment for LCAs involving agricultural production. Int J Life Cycle Ass 2:99-103

Cowell SJ, Clift R (2000) A methodology for assessing soil quantity and quality in life cycle assessment. J Clean Prod 8:321-331

Culley JLB (1993) Density and compressibility. In: Carter MR (ed) Soil sampling and methods of analysis. Louis, Boca Raton, pp 529-539

Di Bene C, Tavarini S, Mazzoncini M, Angelini LG (2011) Changes in soil chemical parameters and organic matter balance after 13 years of ramie [Boehmeria nivea (L.) Gaud.] cultivation in the Mediterranean region. Eur J Agron 35:154-163

Drinkwater LE, Wagoner P, Sarrantonio M (1998) Legume-based cropping systems have reduced carbon and nitrogen losses. Nature 396:262-265

EC (2009) Climate change: Commission dishes the dirt on the importance of soil. EC Communication IP/09/353 Brussels, 5 March 2009, http://europa.eu/rapid/pressReleasesAction.do?reference=IP/09/353

EcoInvent Centre (2007) EcoInvent data v2.0. Swiss Centre for Life Cycle Inventories, Dübendorf, Switzerland

Feller C, Bernoux M (2008) Historical advances in the study of global terrestrial soil organic carbon sequestration. Waste Manage 28:734-740
Finkbeiner M (2009) Carbon footprinting-opportunities and threats. Int J Life Cycle Assess 14:91-94

Forsyth K, Oemcke D (2008) International Wine Carbon Calculator Protocol Version 1.2. Provisor Pty Ltd and Yalumba Wines, Hartley Grove, Urrbrae, SA, 5064, Australia p. 152. www.wfa.org.au/ PDF/International_Wine_Carbon_Calculator_ProtocolV1.2.pdf

Fregoni M (1989) La viticoltura biologica: basi scientifiche e prospettive. Vignevinin 12:7-12

GaBi4 (2007a). GaBi 4 software. http://gabi-software.com

$\mathrm{GaBi} 4$ (2007b) GaBi professional database. http://documentation.gabisoftware.com

Gazulla C, Raugei M, Fullana-i-Palmer P (2010) Taking a life cycle look at crianza wine production in Spain: where are the bottlenecks? Int J Life Cycle Assess 15:330-337

Guinée JB, Gorree M, Heijungs R, Huppes G, Kleijn R, Udo de Haes HA, Van der Voet E, Wrisberg MN (2002) Life cycle assessment. An operational Guide to ISO Standards, vol 1-3. Centre of Environmental Science Leiden University Ed, The Netherlands

Hass G, Wetterich F, Geier U (2000) Life cycle assessment framework in agriculture on farm level. Int J Life Cycle Assess 5:345-348

Hayes P, Battaglene T (2006) Regulatory Response to climate change. Le Bulletin de L'OIV. Organisation Internationale de La Vigne et du Vigne 79:697-708

Hénin S, Dupuis M (1945) Essai de bilan de la matière organique du sol. Ann Agron 15:17-19

Hillier J, Hawes C, Squire G, Hilton A, Wale S, Smith P (2009a) The carbon footprints of food crop production. Int J Agric Sustain 7:107-118

Hillier J, Whittaker C, Dailey G, Aylott M, Casella E, Gm R, Riche A, Murphy R, Taylor G, Smith P (2009b) Greenhouse gas emissions from four bioenergy crops in England and Wales: integrating spatial estimates of yield and soil carbon balance in life cycle analyses. GCB Bioenergy 1:267-281

IPCC (2006) Prepared by the National Greenhouse Gas Inventories Programme. In: Eggleston HS, Buendia L, Miwa K, Ngara T, Tanabe K (eds) IPCC guidelines for national greenhouse gas inventories. IGES, Japan

Janssens IA, Freibauer A, Ciais P, Smith P, Nabuurs GJ, Folberth G, Schlamadinger B, Hutjes RWA, Ceulemans R, Schulze ED, Valentini R, Dolman AJ (2003) Europe's terrestrial biosphere absorbs 7 to $12 \%$ of European anthropogenic $\mathrm{CO}_{2}$ emissions. Science 300:1538-1542

Jenkinson DS (1990) The turnover of organic-carbon and nitrogen in soil. Philos T Roy Soc B 329:361-368

Jenkinson DS, Rayner JH (1977) The turnover of soil organic matter in some of the Rothamsted classical experiments. Soil Sci 123:298-305

Keightley KE (2011) Applying new methods for estimating in vivo vineyard carbon storage. Am J Enol Viticult 62:2

Kemanian AR, Manoranjan VS, Huggins DR, Stöckle CO (2005) Assessing the usefulness of simple mathematical models to describe soil carbon dynamics. Third USDA Symposium on Greenhouse Gases and Carbon Sequestration in Agriculture and Forestry, Baltimore

Koerber GR, Edwards-Jones G, Hill PW, Milà I, Canals L, Nyeko P, York EH, Jones DL (2009) Geographical variation in carbon dioxide fluxes from soils in agro-ecosystems and its implications for life-cycle assessment. J Appl Ecol 46:306-314

Kroodsma DA, Field CB (2006) Carbon sequestration in California agriculture, 1980-2000 Ecol Appl 16:1975-1985

Lal R (2004) Soil carbon sequestration impacts on global climate change and food security. Science 304:1623-1627

Lal R (2008) Carbon sequestration. Philos T Roy Soc B 363:815-830

Li C, Frolking S, Frolking TA (1992a) A model of nitrous oxide evolution from soil driven by rainfall events: 1 . Model structure and sensitivity. J Geophys Res 97:9759-9776 
Li C, Frolking S, Frolking TA (1992b) A model of nitrous oxide evolution from soil driven by rainfall events: 2 . Model applications. J Geophys Res 97:9777-9783

Loveland P, Webb J (2003) Is there a critical level of organic matter in the agricultural soils of temperate regions: a review. Soil Till Res 70:1-18

Manlay RJ, Feller C, Swift MJ (2007) Historical evolution of soil organic matter concepts and their relationships with the fertility and sustainability of cropping systems. Agr Ecosyst Environ 119:217-233

Mary B, Guérif J (1994) Intérêts et limites des modèles de prevision de l'évolution des matières organiques et de l'azote dans le sol. Cah Agric 3:247-257

Mathews A (2011) Post-2013 EU Common Agricultural Policy, Trade and Development: A Review of LegislativeProposals"; ICTSD Programme on Agricultural Trade and Sustainable Development; Issue Paper No.39; International Centre for Trade and Sustainable Development, Geneva, Switzerland, www.ictsd.org

Meisterling K, Samaras C, Schweizer V (2009) Decisions to reduce greenhouse gases from agriculture and product transport: LCA case study of organic and conventional wheat. J Clean Prod 17:222-230

Milà I, Canals L, Burnip GM, Cowell SJ (2006) Evaluation of the environmental impacts of apple production using life cycle assessment (LCA): case study in New Zealand. Agr Ecosyst Environ 114:226-238

Milà I, Canals L, Romanya J, Cowell S (2007) Method for assessing impacts on life support functions (LSF) related to the use of "fertile land" in life cycle assessment (LCA). J Clean Prod 15:1426-1440

Morlat R, Chaussod R (2008) Long-term additions of organic amendments in a Loire Valley Vineyard. Effects on properties of a calcareous sandy soil. Am J Enol Viticult 59:353-363

Mourad AL, Coltro L, Oliveira PAPLV, Kletecke RM, Baddini JPO (2007) A simple methodology for elaborating the life cycle inventory of agricultural products. Int J Life Cycle Assess 12:408-413

Müller-Wenk R, Brandão M (2010) Climatic impact of land use in LCA - carbon transfers between vegetation/soil and air. Int J Life Cycle Assess 15:172-182

Nelson DW, Sommers LE (1982) Total carbon, organic carbon and organic matter. In: Page AL, Miller RH, Keeney DR (eds) Methods of soil analysis, Part 2, Chemical and microbiological properties, Secondth edn. Agronomy Monograph 9, American Society of Agronomy, Madison, WI, pp 539-579

Nemecek T, Erzinger S (2005) Modelling representative life cycle inventories for Swiss arable crops. Int J Life Cycle Assess 10:1-9

Nemecek T, Dubois D, Huguenin-Elie O, Gaillard G (2011) Life cycle assessment of Swiss farming systems: I. Integrated and organic farming. Agr Syst 104:217-232

Notarnicola B, Tassielli G, Nicoletti M (2003) LCA of wine production. In: Mattsonn B, Sonesson U (eds) Environmentally-friendly food processing. Woodhead, Cambridge, pp 306-326

Parat C, Chaussod R, Leveque J, Dousset S, Andreux F (2002) The relationship between copper accumulation in vineyard calcareous soils and soil organic matter and iron. Eur J Soil Sci 53:663-669

Parton WJ, Schimel DS, Cole CV, Ojima DS (1987) Analysis of factors controlling soil organic matter levels in Great Plains grasslands. Soil Sci Soc Am J 51:1173-1179

Petti L, Ardente F, Bosco S, De Camillis C, Masotti P, Pattara P, Raggi A, Tassielli G (2010) State of the art of Life Cycle Assessment (LCA) in the wine industry. 7th International Conference on Life Cycle Assessment in the agri-food sector", Bari, Italy, September 22-24 2010, pp 493-498
Pittock B, Arthington A, Booth T, Cowell P, Hennesy K, Howden M, Hughes L, Jones R, Lake S, Lyne V, McMichael T, Mullet T, Nicholls N, Torok S, Woodruf R (2003) Climate change: an Australian guide to the science and potential impacts. Australian Greenhouse Oice, Canberra, p 239

Pizzigallo CI, Granai C, Borsa S (2008) The joint use of LCA and energy evaluation for the analysis of two Italian wine farms. J Environ Manage 86:396-406

Point EV (2008) Life cycle environmental impacts of wine production and consumption in Nova Scotia. MSc Thesis, Dalhousie University Halifax, Nova Scotia, Canada

Ponsioen TC, Blonk TJ (2011) Calculating land use change in carbon footprints of agricultural products as an impact of current land use. J Clean Prod Available online 21 October 2011

Reap J, Roman F, Duncan S, Bras B (2008) A survey of unresolved problems in life cycle assessment. Int J Life Cycle Assess 13:374 388

Robertson GP, Paul EA, Harwood RR (2000) Greenhouse gases in intensive agriculture: contributions of individual gases to the radiative forcing of the atmosphere. Science 289:1922-1925

Röös E, Sundberg C, Hansson PA (2000) Uncertainties in the carbon footprint of food products: a case study on table potatoes. Int $\mathrm{J}$ Life Cycle Assess 15:478-488

Roy P, Nei D, Orikasa T, Xu Q, Okadome H, Nakamura N, Shiina T (2009) A review of life cycle assessment (LCA) on some food products. J Food Eng 90:1-10

Sinden G (2009) The contribution of PAS 2050 to the evolution of international greenhouse gas emission standards. Int J Life Cycle Assess 14:195-203

Smith P, Martino D, Cai Z, Gwary D, Janzen H, Kumar P, McCarl B, Ogle S, O'Mara F, Rice C, Scholes B, Sirotenko O, Howden M, McAllister T, Pan G, Romanenkov V, Schneider U, Towprayoon S, Wattenbach M, Smith J (2008) Greenhouse gas mitigation in agriculture. Philos T Roy Soc B 363:789-813

Sofo A, Nuzzo V, Palese AM, Xiloyannis C, Celano G, Zukowskyj P, Dichio B (2005) Net $\mathrm{CO}_{2}$ storage in Mediterranean olive and peach orchards. Sci Hortic 107:17-24

Soil Survey Staff (1975) Soil taxonomy: a basic system of soil classification for making and interpreting soil surveys. USDA-SCS Agric. Handb. 436. U.S. Gov. Print. Office, Washington, DC

Soja G, Zehetner F, Rampazzo-Todorovic G, Schildberger B, Hackl K, Hofmann R, Burger E, Omann I (2010) Wine production under climate change conditions: mitigation and adaptation options from the vineyard to the sales booth. 9th European IFSA Symposium, 4-7 July 2010, Vienna (Austria) Proceeding pp 1368-1378. Proceedings Edited by: Ika Darnhofer and Michaela Grötzer Vienna, July 2010 University of Natural Resources and Applied Life Sciences, Vienna ISBN 9783200019089

Steenwerth K, Belina KM (2008) Cover crops enhance soil organic matter, carbon dynamics and microbiological function in a vineyard agroecosystem. Appl Soil Ecol 40:359-369

Webb LB, Whetton PH, Barlow EWR (2007) Impact on Australian Viticulture from Greenhouse Induced Temperature Change. In: Zerger A, Argent RM (eds) MODSIM 2005 International Congress on Modelling and Simulation. Modelling and Simulation Society of Australia and New Zealand, pp 1504-1510

Weidema BP, Thrane M, Christensen P, Schmidt J, Løkke S (2008) Carbon footprint: a catalyst for life cycle assessment? J Ind Ecol $12: 3-6$

Wiedmann T (2009) Editorial: carbon footprint and input-output analysis - an introduction. Econ Syst Res 21:175-186

Wright LA, Kemp S, Williams I (2011) 'Carbon footprinting': towards a universally accepted definition. Carbon Management 2:61-72 